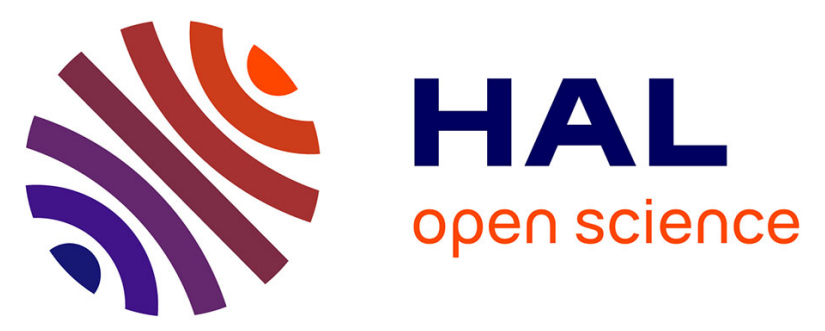

\title{
The tectonometamorphic evolution of the Sesia-Dent Blanche nappes (internal Western Alps): review and synthesis
}

Paola Manzotti, Michel Ballèvre, Michele Zucali, Martin Robyr, Martin Engi

\section{- To cite this version:}

Paola Manzotti, Michel Ballèvre, Michele Zucali, Martin Robyr, Martin Engi. The tectonometamorphic evolution of the Sesia-Dent Blanche nappes (internal Western Alps): review and synthesis. Swiss Journal of Geosciences, 2014, 107 (2-3), pp.309-336. 10.1007/s00015-014-0172-x . insu-01097217

\section{HAL Id: insu-01097217 https://hal-insu.archives-ouvertes.fr/insu-01097217}

Submitted on 27 Nov 2021

HAL is a multi-disciplinary open access archive for the deposit and dissemination of scientific research documents, whether they are published or not. The documents may come from teaching and research institutions in France or abroad, or from public or private research centers.
L'archive ouverte pluridisciplinaire HAL, est destinée au dépôt et à la diffusion de documents scientifiques de niveau recherche, publiés ou non, émanant des établissements d'enseignement et de recherche français ou étrangers, des laboratoires publics ou privés.

\section{(c)(1)}

Distributed under a Creative Commons Attribution| 4.0 International License 


\title{
The tectonometamorphic evolution of the Sesia-Dent Blanche nappes (internal Western Alps): review and synthesis
}

\author{
Paola Manzotti • Michel Ballèvre • Michele Zucali • \\ Martin Robyr • Martin Engi
}

Received: 29 May 2014/Accepted: 6 October 2014/Published online: 24 October 2014

(C) Swiss Geological Society 2014

\begin{abstract}
This study reviews and synthesizes the present knowledge on the Sesia-Dent Blanche nappes, the highest tectonic elements in the Western Alps (Switzerland and Italy), which comprise pieces of pre-Alpine basement and Mesozoic cover. All of the available data are integrated in a crustal-scale kinematic model with the aim to reconstruct the Alpine tectono-metamorphic evolution of the SesiaDent Blanche nappes. Although major uncertainties remain in the pre-Alpine geometry, the basement and cover sequences of the Sesia-Dent Blanche nappes are seen as part of a thinned continental crust derived from the Adriatic margin. The earliest stages of the Alpine evolution are interpreted as recording late Cretaceous subduction of the Adria-derived Sesia-Dent Blanche nappes below the South-Alpine domain. During this subduction, several sheets of crustal material were stacked and separated by shear zones that rework remnants of their Mesozoic cover. The recently described Roisan-Cignana Shear Zone of the Dent Blanche Tectonic System represents such a shear
\end{abstract}

Editorial handling: S. Schmid and A. G. Milnes.

P. Manzotti - M. Robyr $\cdot$ M. Engi

Institute of Geological Sciences, University of Bern,

Baltzerstrasse 1+3, 3012 Bern, Switzerland

P. Manzotti $(\square) \cdot$ M. Ballèvre

Géosciences Rennes, UMR 6118CNRS, Université Rennes1,

Campus de Beaulieu, 35042 Rennes, France

e-mail: paola.manzotti@univ-rennes1.fr

\section{Zucali}

Dipartimento di Scienze della Terra “Ardito Desio", Università degli Studi di Milano, Via Mangiagalli 34, 20133 Milan, Italy

M. Zucali

CNR-IDPA-Sezione di Milano, Via Mangiagalli 34,

20133 Milan, Italy zone, indicating that the Sesia-Dent Blanche nappes represent a stack of several individual nappes. During the subsequent subduction of the Piemonte-Liguria Ocean large-scale folding of the nappe stack (including the Roisan-Cignana Shear Zone) took place under greenschist facies conditions, which indicates partial exhumation of the Dent Blanche Tectonic System. The entrance of the Briançonnais micro-continent within the subduction zone led to a drastic change in the deformation pattern of the Alpine belt, with rapid exhumation of the eclogite-facies ophiolitebearing units and thrust propagation towards the foreland. Slab breakoff probably was responsible for allowing partial melting in the mantle and Oligocene intrusions into the most internal parts of the Sesia-Dent Blanche nappes. Finally, indentation of the Adriatic plate into the orogenic wedge resulted in the formation of the Vanzone back-fold, which marks the end of the pervasive ductile deformation within the Sesia-Dent Blanche nappes during the earliest Miocene.

Keywords Dent Blanche Tectonic System - Subduction · Tectonic erosion · Switzerland · Italy · Austroalpine

\section{Introduction}

Since the pioneering work of Emile Argand (Argand 1916), the Western Alps have been viewed as a classic example of orogeny by nappe stacking (e.g. Collet 1935; Trümpy 1980; Schmid et al. 2004; Pfiffner 2009). Since the days of Argand the following major advances have been made:

1. The distinction between oceanic and continental crust (Elter 1971; Lemoine 1971) has led to a better understanding of the geometry of the nappes; they 
are no longer seen - as Argand did — as necessarily emerging from huge recumbent folds, with basement cores surrounded by their Mesozoic covers.

2. The early stages of ocean opening have been recognized to yield characteristic structures in the distal part of passive margins (ocean-continent transition), such as small-scale blocks of continental crust (i.e. extensional allochthons) tectonically emplaced on top of serpentinized exhumed subcontinental mantle (e.g. Lemoine et al. 1987; Beslier et al. 1993; Froitzheim and Manatschal 1996; Manatschal and Nievergelt 1997; Marroni et al. 1998; Mohn et al. 2012; Beltrando et al. 2014a). The mechanical behaviour of the extending lithosphere has been explored by analogue modelling (e.g. Brun and Beslier 1996) based on offshore data from the Iberian margin (Boillot et al. 1980; Péron-Pinvidic and Manatschal 2009) and field data in the Eastern Alps (Florineth and Froitzheim 1994; Manatschal and Müntener 2009). Extensional allochthons may partly predetermine the geometry of nappe formation during convergence (Dal Piaz 1999; Beltrando et al. 2014a).

3. The deep structure of the Alpine belt has been constrained by geophysical data (seismic and gravimetric), which provides key elements, such as Moho depth and density distribution in deeper parts of the orogen (e.g. Roure et al. 1996; Pfiffner et al. 1997; Schmid and Kissling 2000). Furthermore, numerical models have opened new perspectives on lithospherescale mechanisms of the formation and exhumation of high-pressure rocks (e.g. Burov et al. 2001; Gerya et al. 2002, 2008; Roda et al. 2010, 2012; Spalla et al. 2010; Butler et al. 2013).

4. Advances in metamorphic petrology (thermobarometry) allowed vertical displacements of units to be quantified (Dal Piaz et al. 1972; Ernst 1973; Spalla et al. 1996) and these data have been linked to structural analysis at outcrop to sample scale (Lardeaux et al. 1982; Spalla and Zucali 2004; Spalla et al. 2005). Thus, it became possible to recognize pressure conditions reached by individual units and their subsequent juxtaposition during the orogenic cycle (e.g. Ballèvre and Merle 1993).

5. Geochronological data have become increasingly useful to establish the timing of key metamorphic phases (for a review, see Berger and Bousquet 2008), but relating isotopic age data to particular tectonic events remains a challenge. Recent progress hinges on linking the pressure-temperature $(P-T)$ history of samples to the timing of growth of the minerals dated in the local context of their $P-T$ history (Rubatto 2002; Regis et al. 2014).
6. A sequence of detailed field studies across particularly relevant portions of the Dent Blanche nappe system (Diehl et al. 1952; Canepa et al. 1990; Pennacchioni and Guermani 1993; Roda and Zucali 2008; Manzotti et al. 2014b) have improved our geological understanding, and parts of these results have been integrated in regional papers (e.g. Dal Piaz 1999; Dal Piaz et al. 2010) and maps (e.g. Bonetto et al. 2010).

The present contribution addresses the tectonometamorphic history of the internal Western Alps, based on a review and synthesis of the available data on the SesiaDent Blanche nappes, which corresponds to the "nappe de recouvrement VI" recognized over a century ago by Argand (1906). We first review the lithologies and geometry of the Sesia-Dent Blanche nappes, summarizing results documented in a companion paper (Manzotti et al. 2014b). We then discuss the metamorphic evolution of the nappe system, and then integrate our current understanding in a crustal-scale kinematic model.

\section{Overall geometry of the Sesia-Dent Blanche nappes}

Figure 1 shows the main units involved in the nappe stack of the internal Western Alps (i.e. east of the Valaisan Zone) comprising strongly attenuated continental crust and exhumed mantle (e.g. Beltrando et al. 2014a). The structurally lowest units belong to the Briançonnais Zone derived from the Briançonnais micro-continent (Frisch 1979; Stampfli 1993; Lemoine et al. 2000), with the external part (i.e. Zone Houillère, Vanoise and Grand Saint Bernard) constituting an imbrication of thrust sheets. More internal parts (i.e. the Gran Paradiso and Monte Rosa units) surface in a series of windows below the oceanic units. In the Gran Paradiso massif, such a window reveals a PermoCarboniferous sequence that is probably an equivalent of the Zone Houillère (e.g. Manzotti et al. 2014a).

Units derived from the Piemonte-Liguria Ocean were thrust over the Briançonnais micro-continent. They comprise gabbroic intrusives within mantle peridotite (largely serpentinized); basaltic lava flows and sediments overlie the exhumed mantle sequence. Some units essentially consist of ultramafics, gabbro and basalt (Zermatt-Saas zone), and these enjoyed eclogite-facies metamorphism (Bearth 1967; Dal Piaz and Ernst 1978; Cartwright and Barnicoat 2002; Bucher et al. 2005; Groppo et al. 2009; Rebay et al. 2012). Other units essentially consist of metasediments (Combin zone) that recorded blueschist-facies assemblages (Dal Piaz et al. 1979; Caby 1981; Baldelli et al. 1983; Sperlich 1988; Martin et al. 1994; Negro et al. 2013). 

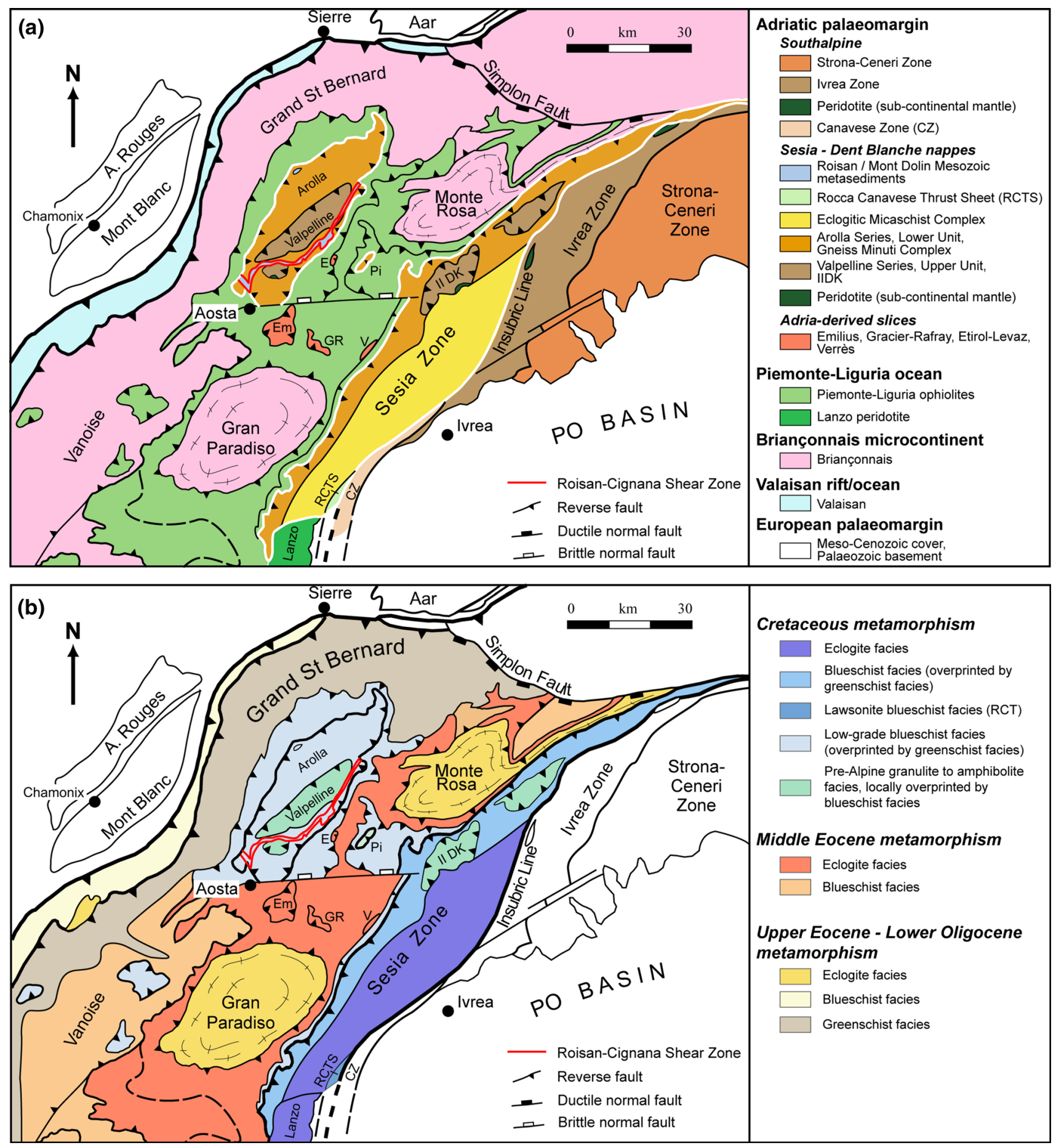

Fig. 1 a Simplified tectonic map of the north-western part of the Western Alps (modified after Le Bayon and Ballèvre 2006). E Etirol Levaz, Em Emilius, GR Glacier-Rafray, $P i$ Pillonet, $V$ Verrès. Because of their small sizes, the Santanel, Tour Ponton, and Acque Rosse basement slices are not shown in the map. The outlines of the

Thrust on top of the Piemonte-Liguria units is the highest tectonic element, whose tectonometamorphic history is the main topic of this paper. It consists of various
Dent Blanche Tectonic System, the Pillonet klippe, and the Sesia Zone (together referred to as the Sesia-Dent Blanche nappes) are marked by white lines; b Metamorphic map of the same area. The map combines the age and the grade (i.e. the metamorphic facies) of the Alpine metamorphism

pieces of pre-Alpine basement derived from the distal continental margin of Adria. Such fragments have often been referred to as "Austroalpine" in the literature, but 
their metamorphic history and tectonic position are different to the Austroalpine units of eastern Switzerland and Austria (see Froitzheim et al. 1996 and further discussion below). Two major complexes surface in the area addressed here: the more internal Sesia Zone stretches from the Insubric line to the eastern margin of the Piemonte-Liguria unit; the more external Dent Blanche klippe (Argand 1911; Stutz and Masson 1938; Elter 1960; Compagnoni 1977) forms a giant outlier $\left(>4,000 \mathrm{~km}^{2}\right)$. The Dent Blanche klippe has long been recognized to root in the Sesia Zone (Diehl et al. 1952; Elter 1960; Compagnoni 1977). The present study thus adopts the term Sesia-Dent Blanche nappes as a generic name for this entire composite thrust sheet, which overlies the Combin zone (including the Tsaté unit).

The Sesia Zone (size $\sim 140 \times 25 \mathrm{~km}$ ) consists of a polycyclic meta-sedimentary basement intruded by granitoid and gabbroic bodies (Dal Piaz et al. 1972; Compagnoni et al. 1977a) of Carboniferous and Permian age (Paquette et al. 1989; Cenki-Tok et al. 2011). The Sesia Zone has been classically divided into three sub-units (Fig. 2): (i) the Gneiss Minuti Complex (GMC), (ii) the Seconda Zona Diorito-Kinzigitica (II DK), (iii) the Eclogitic Micaschists Complex (EMC). The early Alpine eclogite to blueschist facies imprint recorded in these subunits is of variable intensity, as well as is the (scant to pervasive) re-equilibration to greenschist facies conditions (Dal Piaz et al. 1972; Compagnoni et al. 1977a; Gosso 1977; Lardeaux et al. 1982; Vuichard 1989; Tropper and Essene 2002; Zucali et al. 2002; Regis et al. 2014). In the south-western part of the Sesia Zone, the Rocca Canavese Thrust Sheet (RCTS; some $10 \mathrm{~km}$ long and at most $2.5 \mathrm{~km}$ thick) (Pognante 1989a, b; Spalla and Zulbati 2003; Zucali et al. 2012) comprises thin slices at the boundary between the EMC and the Canavese Zone. The RCTS consists of an assemblage of mantle-derived lithologies (serpentinised tectonitic lherzolites) and crustal rocks (pre-Alpine granulites, meta-granitoids, glaucophane-bearing schists). The dominant metamorphism is under blueschist facies, with abundant syn-kinematic lawsonite (Pognante 1989a).

The Dent Blanche klippe $(\sim 52 \times 15 \mathrm{~km})$, often referred to the literature as Dent Blanche klippe s.l. and now renamed the Dent Blanche Tectonic System (DBTS; Manzotti et al. 2014a, b), constitutes the largest continental klippe now exposed above the surrounding oceanic domain (Figs. 1a, 2). It comprises two main basement nappes, i.e. the Dent Blanche s.s. nappe to the northwest and the Mont Mary nappe to the southeast. The former is made up of two superimposed lithological associations, i.e. the Valpelline and the Arolla Series (Argand 1906, 1908; Diehl et al. 1952). The Mont Mary nappe also includes two different lithological units, simply termed the Upper and Lower Units (Canepa et al. 1990; Dal Piaz et al. 2010). The Dent Blanche s.s. and Mont Mary nappes are separated by a $25 \mathrm{~km}$ long shear zone, defined as the Roisan-Cignana Shear Zone (RCSZ) (Manzotti 2011; Manzotti et al. 2014a, b). This shear zone contains pre-Alpine rocks sheared and folded together with Mesozoic meta-sediments. The Pillonet klippe (Figs. 1a, 2) is by far smaller $(\sim 5 \times 2 \mathrm{~km})$ compared to the DBTS and crops out at about midway

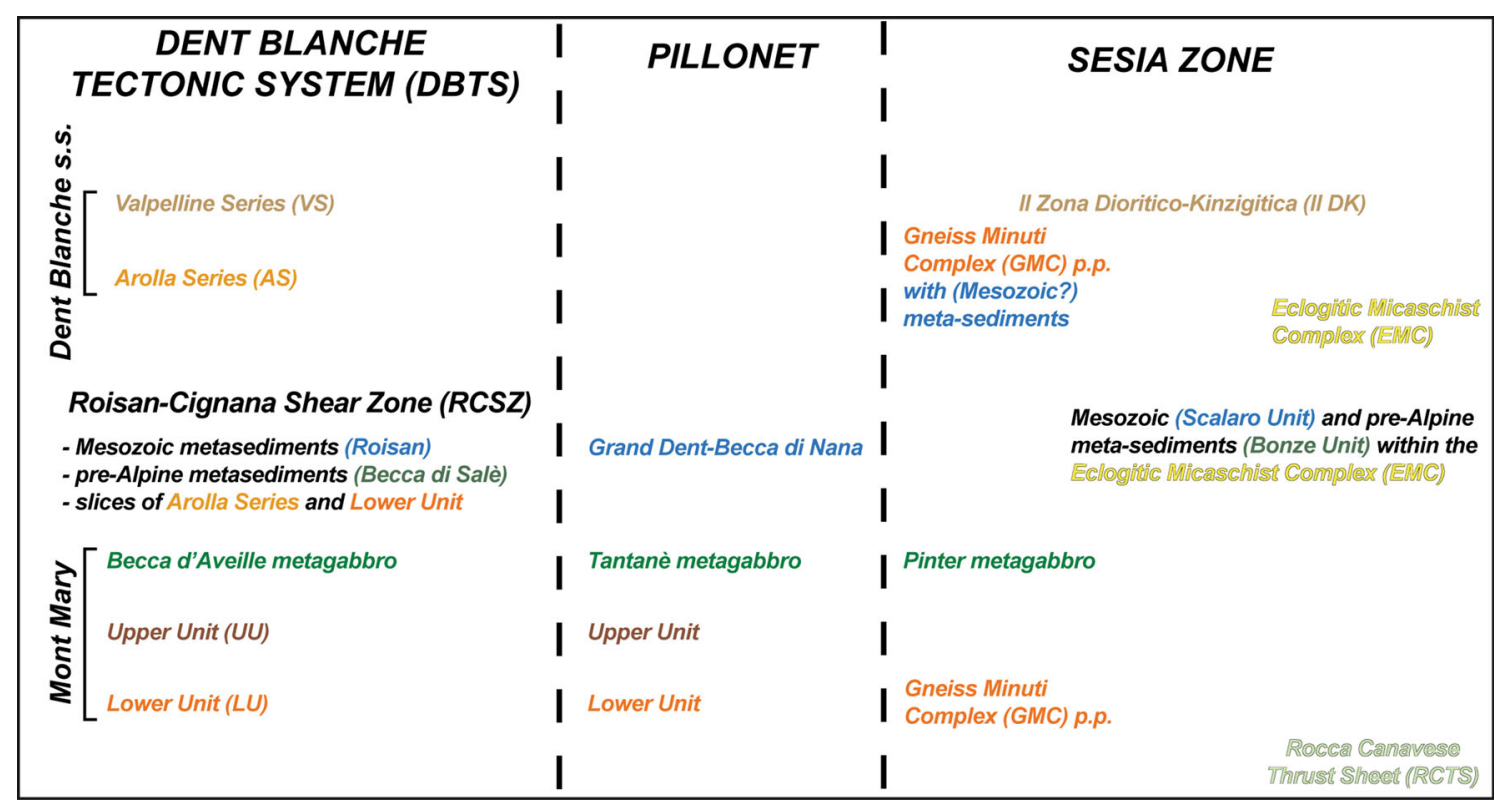

Fig. 2 Tectonic units constituting the Dent Blanche Tectonic System (Dent Blanche s.s. and Mont Mary nappes), the Pillonet klippe, and the Sesia Zone, arranged according to their pre-Alpine position within the Adria-derived basement. Lithological correlations among these tectonic units are shown 
between Dent Blanche s.l. klippe and Sesia Zone (Dal Piaz 1976).

Other fragments possibly derived from the Adria distal continental margin (i.e. the Etirol-Levaz, the Emilius, the Glacier-Rafray and the Verrès slices), are located at a lower structural level, i.e. on top of eclogite-facies oceanic units rather than on top of the Combin Zone (Ballèvre et al. 1986; Dal Piaz 1999). However, these fragments cannot be considered as "lower digitations" of the "nappe de recouvrement VI" (Argand 1934) because the meta-sediments and ophiolites underlying the DBTS are not equivalent to those underlying the Etirol-Levaz-type slices. Indeed, a significant gap in $P-T$ conditions is observed along a tectonic contact that separates the two types of units (Dal Piaz 1965; Bearth 1967; Kiénast 1973), a feature that was not yet known at the time of Argand's synthesis. Therefore, these slices are not part of the Sesia-Dent Blanche nappes and will not be included in the following account.

To the east of the Sesia Zone, the adjacent Canavese Zone (Argand 1909; Novarese 1929) consists of a few slices of meta-peridotites, Permian granitoids and rhyolites, and a Mesozoic cover including syn-rift sequences of tectono-sedimentary breccias and deep-water clastics, topped by a post-rift sequence (Elter et al. 1966; Ferrando et al. 2004). The Canavese Zone displays brittle deformation during the Alpine orogeny and completely lacks highpressure metamorphism; it may represent part of an oceancontinent transition zone (Ferrando et al. 2004; Beltrando et al. 2014b).

\section{Permian record in the Sesia-Dent Blanche nappes}

The main criteria for inferring the pre-Alpine position of the various units within the Adria-derived basement (Fig. 2) are: (i) the $P-T$ conditions of the late-Palaeozoic metamorphism, and (ii) the nature and distribution of the magmatic rocks. For the Sesia-Dent Blanche nappes, these key elements are outlined in the following text and in Fig. 3.

\subsection{Petrological data on the pre-Alpine metamorphism}

The Valpelline Series of the Dent Blanche s.s. nappe (Gardien et al. 1994; Manzotti and Zucali 2013), the Upper Unit of the Mont Mary nappe (Canepa et al. 1990), and the II DK in the Sesia Zone (Carraro et al. 1970; Dal Piaz et al. 1971, 1972; Vuichard 1987) display, at least locally, partially melted paragneiss ("kinzigite") that preserves preAlpine high-temperature assemblages (Dal Piaz et al. 1971; Compagnoni et al. 1977a; Gosso et al. 1979; Lardeaux et al. 1982; Ballèvre et al. 1986; Dal Piaz et al. 2010; Manzotti et al. 2012). $P-T$ estimates for pre-Alpine metamorphism cluster around $6-8 \mathrm{kbar}, 700$ to $850{ }^{\circ} \mathrm{C}$, i.e. upper amphibolite to granulite facies conditions (Fig. 3). This high-grade metamorphism is of Permian age based on U-Pb geochronology (Zucali et al. 2011; Manzotti 2012). In these units, as in the Pillonet klippe, the Alpine structural and metamorphic overprint is highly variable.

Relics of pre-Alpine metamorphism are locally also found in the EMC, such as garnet-sillimanite assemblages in metapelites (in the Monte Mucrone area, Dal Piaz et al. 1972; Compagnoni 1977) and amphibole-plagioclasebiotite-quartz \pm orthopyroxene in amphibolites (Lardeaux et al. 1982; Gosso et al. 2010). $P-T$ conditions for these assemblages have been estimated at about 7-11 kbar and $700-800^{\circ} \mathrm{C}$ (Lardeaux et al. 1982), or $3.5 \pm 1 \mathrm{kbar}$ and $700{ }^{\circ} \mathrm{C}$ (Gosso et al. 2010). Both of these sets of $P$ $T$ conditions have been attributed to Permian metamorphism as well, but this awaits a radiometric confirmation.

\subsection{Pre-Alpine magmatism}

Abundant evidence for pre-Alpine magmatism is found in the Sesia-Dent Blanche nappes, with bulk-rock chemistries ranging from gabbro to granite. Most of the dated intrusions are Permian (e.g. Bussy et al. 1998; Monjoie et al. 2007), a few of them are older (e.g. Liermann et al. 2002).

The Arolla Series of the Dent Blanche s.s. nappe mainly consists of granitoids of Permian age (Bussy et al. 1998; Manzotti 2012) and their ortho-derivates, while para-derivates are lacking except for the rare occurrence of lenses of biotite-bearing gneiss and amphibolite interpreted as roof pendants (Roda and Zucali 2008, 2011). The Lower Units of the Mont Mary nappe (Dal Piaz et al. 2010) and the Pillonet klippe (Dal Piaz 1976) on the one hand, and the GMC of the Sesia Zone on the other hand (Compagnoni et al. 1977a) are essentially made of granitoids and minor para-derivates.

Permian meta-gabbro bodies of various sizes occur in all these units. Classic examples are found in the DBTS, such as the Collon-Matterhorn group and Becca d'Aveille (Dal Piaz 1997; Monjoie et al. 2007; Dal Piaz et al. 2010; Baletti et al. 2012). Other occurrences are known in the Pillonet (i.e. Tantanè, Dal Piaz 1976), as well as in the frontal (external) part of the Sesia Zone, in the Pinter area and in the Anzasca (=Sermenza) valley (Dal Piaz et al. 1971; Gosso et al. 1979; Spalla et al. 1983, 2014; Dal Piaz 1997; Bussy et al. 1998).

In the Sesia Zone, most of the geochronological data from the intrusives (Table 1) indicate Permian magmatism of dominantly granitic to granodioritic composition. PrePermian intrusives tend to be less silicic and occur in the EMC, e.g. monzogranite sills (ca. 435 to $400 \mathrm{Ma}$; Liermann et al. 2002) and gabbro stocks (ca. $350 \mathrm{Ma}$; Rubatto and Gebauer 1997). 


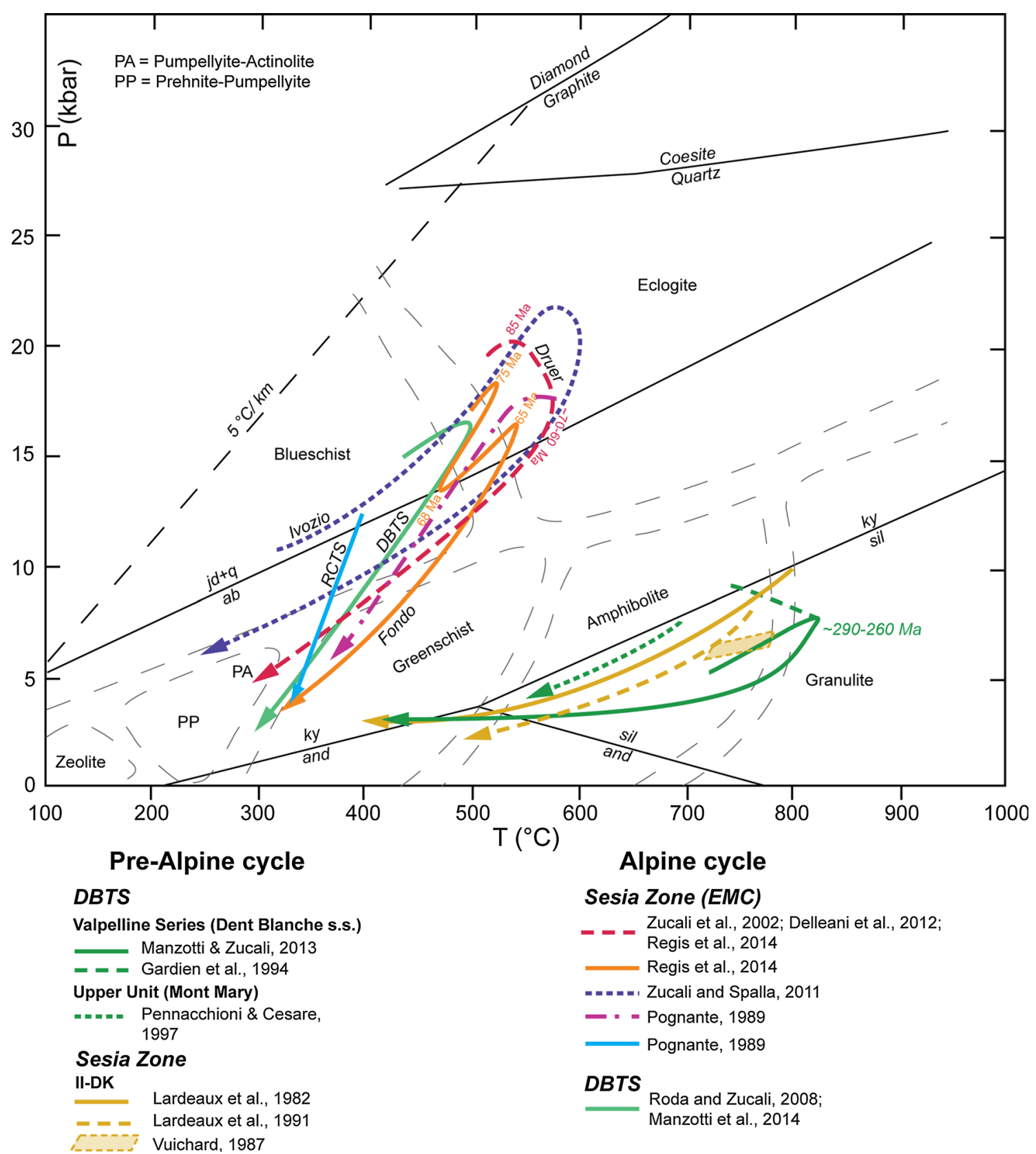

Fig. 3 Pre-Alpine and Alpine $P-T$ paths, reconstructed for the units constituting the DBTS (Dent Blanche Tectonic System) and the Sesia Zone. Note the differences in the Alpine trajectories and their relative timing within the EMC (Eclogitic Micaschist Complex)

\subsection{Inferred pre-Alpine crustal structure}

In order to understand the pre-Alpine crustal position of the units that make up the Sesia-Dent Blanche nappes, a reference section is useful. A coherent record is conveniently available from the nearby South Alpine crust (Ivrea Zone and Strona-Ceneri Zone of Fig. 1), where a tilted section through the complete crust has been identified (Fountain 1976; Quick et al. 2003, 2009; Sinigoi et al. 2009). Deposits from acid explosive volcanism are underlain by upper crust, dominantly large granitoids that intruded paragneisses. This amphibolite-facies basement locally retains evidence of a pre-Permian orogenic cycle (StronaCeneri Zone; Franz and Romer 2007). The lower crust exposed in the Ivrea Zone consists of upper amphibolite to granulite facies paragneisses, intruded by massive gabbroic bodies (termed the Basic Formation). The late-Palaeozoic evolution of this crustal section may be explained by partial melting in the upper mantle during crustal extension and subsequent magmatic underplating at the Moho transition, 
Table 1 Geochronological data from gabbros and granites emplaced in the Sesia-Dent Blanche nappes

\begin{tabular}{|c|c|c|c|c|}
\hline Location & Lithologies & Method & Age (Ma) & References \\
\hline \multirow[t]{8}{*}{ Sesia Zone } & Orthogneiss (Tavagnasco, Montestrutto) & $\mathrm{U} / \mathrm{Pb}$ & $\begin{array}{l}435 \pm 8 \\
396 \pm 21\end{array}$ & Liermann et al. (2002) \\
\hline & Gabbro (Cima di Bonze) & $\mathrm{U} / \mathrm{Pb}$ & $352 \pm 8$ & Rubatto et al. (1999) \\
\hline & Gabbro (Ivozio) & $\mathrm{U} / \mathrm{Pb}$ & $355 \pm 9$ & Rubatto et al. (1998) \\
\hline & Granite (Monte Mucrone) & $\mathrm{U} / \mathrm{Pb}$ & $286 \pm 2$ & Paquette et al. 1989 \\
\hline & & & $293 \pm 2$ & Bussy et al. (1998) \\
\hline & & & $297 \pm 18$ & Rubatto et al. (1999) \\
\hline & & $\mathrm{Th} / \mathrm{Pb}$ & $287 \pm 7$ & $\begin{array}{l}\text { Cenki-Tok et al. } \\
\quad \text { (2011) }\end{array}$ \\
\hline & Gabbro (Sermenza) & $\mathrm{U} / \mathrm{Pb}$ & $288 \pm 4$ & Bussy et al. (1998) \\
\hline \multirow[t]{3}{*}{$\begin{array}{l}\text { Dent Blanche } \\
\text { s.s. }\end{array}$} & Gabbro (Matterhorn Collon) & $\begin{array}{l}\mathrm{K} / \mathrm{Ar} \mathrm{Rb} / \\
\mathrm{Sr}\end{array}$ & $250 \pm 5$ & Dal Piaz et al. (1977) \\
\hline & & $\mathrm{U} / \mathrm{Pb}$ & $284 \pm 1$ & Monjoie et al. (2007) \\
\hline & $\begin{array}{l}\text { Mafic dikes (Mont Collon Dents de } \\
\text { Bertol) }\end{array}$ & $\mathrm{Ar} / \mathrm{Ar}$ & $\sim 260$ & Monjoie et al. (2007) \\
\hline
\end{tabular}

with high heat flow inducing partial melting of the lower crust. The resulting magmas migrated upward and either collected in large granitoid plutons or led to eruptions, forming caldera-like volcanoes in the Permian. In detail, uncertainties remain regarding (i) the geometry and kinematics of high-temperature shear zones, (ii) their temporal relation to the granulite-facies metamorphism, and (iii) the exact timing of the magmatic underplating with respect to the regional granulite-facies event. The crustal section was modified during Triassic to Jurassic rifting and during the Alpine orogeny as well (Handy et al. 1999), but the main features of this reference section are preserved as shown in Fig. 4.

Based on that section and its implications for the DBTS, we agree with earlier studies (Compagnoni et al. 1977a; Dal Piaz 1993) that the Valpelline Series, the Upper Unit of the Mont Mary nappe, and the II DK represent slices of the late-Palaeozoic lower crust. The main argument for this view is that (i) these units consist of high-temperature rocks equilibrated at 6-8 kbar, (ii) they display abundant evidence of partial melting, and (iii) they lack granitoid intrusions. By contrast, the Arolla Series is typical upper crust, predominantly formed by Permian granitoids. The EMC contains large amounts of pre-Alpine paragneiss (locally with garnet-biotite-sillimanite relics, Dal Piaz et al. 1972; Compagnoni 1977) intruded by Permian granitoids. These features identify the EMC as a fragment of the Permian middle crust or possibly of lower crust already partly exhumed prior to Permian magmatism.

\section{Triassic-Jurassic record in the Sesia-Dent Blanche nappes}

In the Sesia-Dent Blanche nappes, meta-sediments record a Mesozoic evolution. The main lithostratigraphic

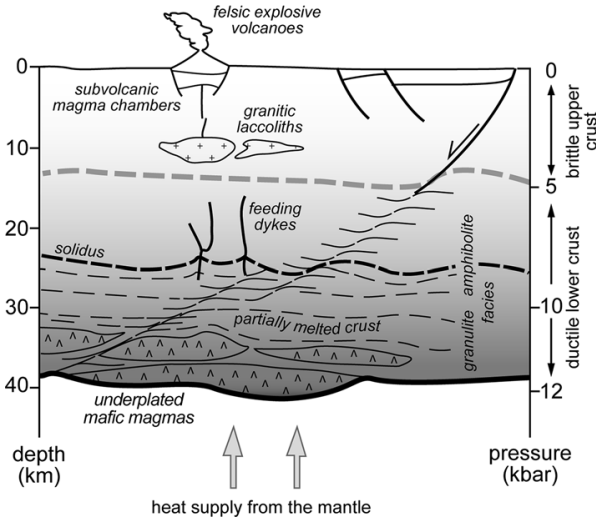

Fig. 4 Sketch of the continental crust during the Permian, based on the known structure of the Ivrea Zone, and used as a model for discussing the position of subducted units prior to their Alpine history

characteristics are still recognizable. Mesozoic meta-sediments were first identified in the Mont Dolin Series (Argand 1906), where Triassic dolomite and Liassic marbles are overlain by a thick sequence of Liassic to ?Dogger breccias (Hagen 1948; Weidmann and Zaninetti 1974; Ayrton et al. 1982). The most widespread Mesozoic metasediments (named Roisan Zone) are located in the RCSZ, that marks the contact between the Mont Mary and the Dent Blanche s.s. nappes (Elter 1960; Ballèvre et al. 1986; Canepa et al. 1990; Ciarapica et al. 2010; Manzotti et al. 2014a, b). Originally considered as part of the Combin Zone (Diehl et al. 1952), these meta-sediments are now interpreted as members of the RCSZ (Manzotti et al. 2014a, b). The Roisan meta-sediments are very similar to the Grand Dent-Becca di Nana Complex found in the Pillonet klippe (Dal Piaz 1976).

In the Sesia Zone, slices of carbonate meta-sediments have also been found; where these display dolomitic boudins, they are thought to be Mesozoic in origin: 
1. Such meta-sediments were reported within the GMC, along the divide between the Gressoney valley and the Sesia valley along a shear zone at the Passo dell'Uomo Storto (Dal Piaz et al. 1971; Gosso et al. 1979, plate I); in the Aosta valley, dolomite marbles surface along the boundary between the GMC and EMC in the Cima delle Pietre Bianche (sic!) area (Compagnoni et al. 1977b, Fig. 3; Vuichard 1987, Fig. 1.5 and simplified geological map). Several other occurrences of presumed Mesozoic meta-sediments have been mapped in the south-western part of the Sesia Zone (Spalla et al. 1983).

2. Most of the presumed Mesozoic meta-sediments are found within the EMC, however, mostly near its northwestern boundary that is often overprinted at greenschist facies conditions. The Bonze unit (Venturini et al. 1991, 1994; Venturini 1995) includes carbonate, minor quartzite and calc-schist, Mn-chert, and micaschist; all of these lithologies are presumed to be Mesozoic in age, a hypothesis utilized also by Babist et al. (2006). However, contrary to the ideas of Venturini and coworkers, meta-gabbros associated with the meta-sediments of the Bonze unit show Early Carboniferous intrusive ages (Rubatto and Gebauer 1997; Rubatto et al. 1999), and thus the stratigraphic age of associated sediments and their relation to the mafic rocks may need reconsidering. Recent work (Regis et al. 2014; Compagnoni et al. 2014) distinguished the Scalaro Unit from the Bonze Unit (Fig. 2); the former comprises mono-metamorphic carbonate, quartzite and calc-schist, all of presumed Mesozoic age; the latter contains poly-metamorphic gabbro and associated meta-sediments (meta-chert and micaschist) of uncertain deposition age.

The presence of Mesozoic meta-sedimentary sequences and their similarity to less overprinted Mesozoic sedimentary sections have been used to assess the pre-orogenic (Jurassic) palaeogeographic position of the Sesia-Dent Blanche nappes. On the one hand, Lugeon and Argand (1905) and Argand (1906, 1909, 1911) considered their "nappe de recouvrement VI" as Penninic, since the sedimentary sequences of the Mont Dolin show similarities with those in the Valaisan zone (Haute Savoie Val Ferret and Sion areas), especially with the Jurassic breccias of the Grand Fond Formation (Antoine et al. 1972). Other authors (Hagen 1948; Weidmann and Zaninetti 1974; Ayrton et al. 1982) compared the cover sequence of the Mont Dolin to the Mesozoic sequence of the Lower Austroalpine Err nappe, especially to the polygenic breccias from the Saluver Formation in the Samedan basin (Handy 1996; Masini et al. 2012). Today, strict analogies between the facies of Mesozoic sequences are no longer used as a primary tool in reconstructing the palaeogeography. Rather, the accent is put on recognizing syn- and post-rift sedimentary sequences. Notably breccias, to whichever unit they may belong, serve as indicators of syn-sedimentary tectonics, and the presence of characteristic clasts (of quartzite and Arollatype granitoids) in the Mont Dolin sequence record erosion of a nearby basement. Collectively, the observed features indicate a transition from high- to low-angle normal faulting that accommodated exhumation of the basement (Masini et al. 2011). The lack of basement clasts in the breccias of the Roisan sequence (Manzotti et al. 2014a, b) indicates that they were deposited in a different environment, either at greater distance from syn-sedimentary faults or in an area where crustal thinning was less important than near the Mont Dolin area.

\section{Alpine evolution of the Sesia-Dent Blanche nappes}

Every unit constituting the Sesia-Dent Blanche nappes show evidence of Alpine ductile deformation associated with high pressure-low temperature metamorphism, overprinting pre-Alpine structures and metamorphism (Fig. 3). However, the amount of Alpine reworking is heterogeneous, from almost no signs of strain and metamorphism in parts of the Valpelline Series and II DK, to strong and pervasive overprinting under eclogite facies (EMC) and/or greenschist facies (Arolla Series, GMC) conditions.

\subsection{Alpine metamorphism}

Key observations include the maximum pressures recorded in each unit during its subduction history, since differences in peak $P$ conditions may record differences in depth. Importantly, discontinuities in $P-T$ conditions across a ductile shear zone bounding two units, or even within a unit, record displacements following the early stages of subduction.

In the Sesia Zone, the EMC reached eclogite facies conditions of about 16-22 kbar and 500-600 ${ }^{\circ} \mathrm{C}$ (Compagnoni 1977; Compagnoni et al. 1977a; Gosso 1977; Lardeaux 1981; Lardeaux et al. 1982; Pognante et al. 1987; Pognante 1989a; Lardeaux and Spalla 1991; Spalla et al. 1991; Zucali et al. 2002; Matsumoto and Hirajima 2005; Regis et al. 2014). Eclogite-facies conditions in the south (Corio-Monastero metagabbro: Rebay and Messiga 2007) are similar to those observed some $50 \mathrm{~km}$ to the north (Monte Mucrone area: Zucali et al. 2002; Delleani et al. 2012, 2013b), and the metamorphic field gradient along strike is weak or absent in the internal part of the Sesia Zone. Across strike, however, a recent work has shown that various parts of the EMC display different $P-T$ paths 
(Zucali and Spalla 2011). Notably, estimated pressures in the most internal part of the EMC (Druer slice) are distinctly higher (and were reached earlier) than in the more external part (Fondo slice; Regis et al. 2014). The EMC thus appears to comprise distinct tectonic slices that were accreted under a range of eclogite-facies conditions and over a period from ca. 84 to $70 \mathrm{Ma}$ (Regis et al. 2014). The boundaries between these subunits remain to be mapped.

In the GMC, high-pressure minerals or parageneses have locally been recorded (Williams and Compagnoni 1983; Spalla et al. 1991), but in all parts the greenschist facies parageneses are predominant. Alpine pressures and temperatures recorded in the EMC are considerably higher (and better constrained) than in the GMC (Pognante et al. 1987; Lardeaux and Spalla 1991; Zucali et al. 2002; Matsumoto and Hirajima 2005).

In the II DK, Alpine metamorphism is only very locally visible for kinetic reasons. It occurs mainly in shear zones bounding the II DK along its contact to the EMC, or in shear zones inside the II DK located near the boundary with the EMC. Garnet-glaucophane, garnet-chloritoid \pm kyanite, and garnet-clinopyroxene (mainly $\mathrm{Jd}$ $35 \%$ ) assemblages indicate that the contact between the EMC and the II DK developed at about $14 \mathrm{kbar}$ and $500{ }^{\circ} \mathrm{C}$ (Lardeaux et al. 1982; Ridley 1989; Vuichard 1989; Bistacchi et al. 1997).

Blueschist facies metamorphism has been described from the DBTS (Fig. 3) and the Pillonet klippe, but the intense greenschist-facies overprint (Diehl et al. 1952; Dal Piaz and Nervo 1971; Dal Piaz 1976; Compagnoni et al. 1977a; Ayrton et al. 1982; Canepa et al. 1990; Dal Piaz et al. 2010; Manzotti et al. 2014a, b) makes quantifications difficult. Well preserved blueschist facies assemblages (statically overprinted by pumpellyite) are found in the RCTS, with $P-T$ conditions estimated at around 10-15 kbar and 300-400 ${ }^{\circ} \mathrm{C}$ (Pognante 1989b).

\subsection{Alpine strain}

The heterogeneous distribution and polyphase record of Alpine (versus pre-Alpine) deformation renders tectonic correlations difficult at the scale of the entire thrust sheet, i.e. the Sesia-Dent Blanche nappes. Superimposed strain patterns are documented in the Dent Blanche s.s. (Pennacchioni and Guermani 1993; Roda and Zucali 2008; Manzotti and Zucali 2013; Manzotti et al. 2014a, b), in the Mont Mary nappe (Canepa et al. 1990), in the Pillonet klippe (Dal Piaz and Sacchi 1969; Vogler 1984), and in the Sesia Zone (e.g. Gosso 1977; Passchier et al. 1981; Williams and Compagnoni 1983; Zucali et al. 2002, 2013). Efforts of correlation across the nappe stack (Dal Piaz 1993, 1999; Babist et al. 2006) have deciphered essential parts of the subduction-exhumation related strain record, but these studies did not address the external parts, notably the Dent Blanche klippe, in any detail. Moreover, the major role of the RCSZ has been recognized only very recently (Manzotti et al. 2014a, b).

The intensity of Alpine strain varies, either from one unit to the next, or even within similar rock types and/or within the same unit. In the EMC, small volumes of rocks (about $0.01 \times 0.01 \times 0.1 \mathrm{~km}$ ) that were left undeformed by the Alpine orogeny have been found, e.g. in the Monte Mucrone meta-granite (Dal Piaz et al. 1972; Compagnoni and Maffeo 1973; Oberhänsli et al. 1985; Zucali et al. 2002; Delleani et al. 2012, 2013a), in the Lago della Vecchia meta-granite (Dal Piaz et al. 1972; Zucali 2011), and in lenses of pre-Alpine para-gneisses or meta-gabbros (Dal Piaz et al. 1972; Lardeaux and Spalla 1991). In the II DK large rock volumes $\left(1 \mathrm{~km}^{3}\right)$ still preserve pre-Alpine structures (Dal Piaz et al. 1971; Ridley 1989; Vuichard 1989), and the same is true for the Valpelline Series $(10 \times 5 \times 2 \mathrm{~km})($ Diehl et al. 1952; Nicot 1977; Gardien et al. 1994; Manzotti and Zucali 2013). In the Arolla Series and in the Lower Unit of the Mont Mary, mapping has revealed a few undeformed granitoids and gabbros as well (Diehl et al. 1952; Elter 1960; Roda and Zucali 2008; Manzotti 2011; Roda and Zucali 2011). By contrast, the GMC shows pervasive Alpine deformation, undeformed volumes being conspicuously absent.

Overall, strain intensity increases going (i) from lower crustal units to intermediate and higher crustal units, and (ii) from west to east (i.e. across strike) for the same lithologies. This is attributed to a combination of two processes. Firstly, the lower crustal units were strongly dehydrated during the pre-Alpine evolution, and highgrade assemblages did not readily convert to blueschistfacies or eclogite-facies assemblages. Pervasive Alpine reequilibration was achieved in narrow shear zones only, whereas unstrained rock volumes only display coronitic reaction textures. Secondly, peak $P-T$ conditions during Alpine orogeny may have varied across strike. For instance, meta-granitoids display nice jadeite- or omphacite-bearing parageneses in the most internal domain (Monte Mucrone), whereas mostly albite was preserved in the most external domain, except in a few samples where crossite \pm aegirine are found (Ayrton et al. 1982; Pennacchioni and Guermani 1993; Roda and Zucali 2008). Provided these pressure conditions were attained at the same time (which is still uncertain), this would suggest that the different units now assembled in the Sesia-Dent Blanche nappes were subducted towards the SE.

Apart from the (Mesozoic) meta-sediments, characteristic lithotypes within the basement may also be useful in tracing major shear zones. In particular, pre-Alpine granulites grading into fine-grained schists, with a characteristic red-brown alteration, have been reported. (i.e. red schists 
described in the Upper Unit of the Mont Mary nappe and Pillonet klippe, and in the II DK of the Sesia Zone; Bertolani 1964; Dal Piaz et al. 1971, 2010; Dal Piaz 1976; Manzotti et al. 2014a, b). Although these slices of red schists have been pervasively obliterated by the Alpine structural and metamorphic imprint, they probably derive from granulites, i.e. from lower crust.

Each tectonic unit shows a specific relative chronological sequence of superimposed structures and specific relationships between deformation and metamorphism (e.g. Dal Piaz and Sacchi 1969; Vogler 1984; Vuichard 1986; Canepa et al. 1990; Zucali and Spalla 2011; Manzotti et al. 2014a, b). The amount of strain and the timing of ductile deformation with respect to the $P$ $T$ history may differ significantly between the various units. Specifically, some units (Arolla Series, GMC) are characterized by a dominant fabric acquired during greenschist-facies conditions, while others nicely preserve ductile fabrics that developed during eclogite-facies conditions (EMC). The latter, in addition to the differences in metamorphic age and pressure conditions (Pognante 1989a; Zucali et al. 2002 and refs. therein; Regis et al. 2014) show discrepancies in the deformation fabrics acquired during exhumation (e.g. dominantly D3 in the west, but D5 in the east; Babist et al. 2006) (see Figs. 3, 5).

Some authors have proposed that the GMC and EMC represent different tectonic units, with distinct $P-T$ paths (Passchier et al. 1981; Williams and Compagnoni 1983; Vuichard 1987). One major question is whether the units with a dominant greenschist-facies fabric have been pervasively deformed during an earlier stage at high pressure or not. Spalla et al. (1991) state that this was the case for the GMC because they observed relics of high- $P$ parageneses. These authors infer the existence of a gradient of greenschist-facies deformation through the Sesia Zone, i.e. an increase in strain from the southeast to the northwest. At the scale of the Sesia-Dent Blanche nappes, a few observations (high- $P$ relics) indicate an overall increase in peak $P$ from northwest to southeast, but with a gradient in the overprint owing to greenschist-facies deformation (Spalla and Zulbati 2003). Alternatively, we surmise the existence of different slices-with distinct peak $P$-that were stacked during exhumation and accompanied by greenschist-facies deformation. The critical question remains how to identify and characterize tectonic boundaries within the Sesia-Dent Blanche nappes.

\subsection{Tectonic boundaries within the Sesia-Dent Blanche nappes}

Tectonic boundaries within the Sesia-Dent Blanche nappes may be defined using a combination of criteria including (i) the presence of Mesozoic (meta)-sedimentary layers or thrust sheets at the contact between basement rocks, (ii) differences in pre-Alpine structure and metamorphism, and (iii) differences in Alpine structure, metamorphism and age. None of these criteria is unambiguous on its own, except, as recognized by Babist et al. (2006), the presence of Mesozoic meta-sediments, which necessarily indicates a tectonic boundary. Due to intense deformation following nappe formation, the original nappe boundary may have been folded and/or transposed, with the Mesozoic sediments folded and/or boudinaged along the former tectonic boundary. As a result, potential nappe boundaries become very difficult to recognize.

The only indisputable nappe boundary recognized up to now within the DBTS is the RCSZ (Elter 1960; Canepa et al. 1990; Manzotti et al. 2014a, b; see Fig. 1). Within the Sesia Zone, nappe boundaries have also been proposed, based on the occurrence of carbonate meta-sediments of presumed Mesozoic age in association with contrasting pre-Mesozoic lithologies and Alpine metamorphic histories in places where such meta-sediments are missing (Babist et al. 2006). The relative timing of nappe emplacement may be defined using polyphased mineral assemblages that define superposed fabrics along the shear zone bounding the thrust sheet or inside the thrust sheet. Specifically, in the case where no discontinuity in $P-T-t$ conditions is recorded across a shear zone, this indicates either a minor amount of displacement across the shear zone, or that such displacements took place prior to the onset of retrogression. The precise timing of displacement along the shear zone can be determined only if the exact shape of the $P-T$ paths is known in each unit. Juxtaposition during subduction has been assumed for the RCSZ (Manzotti et al. 2014a, b). However, the exact geometry and age of most of the tectonic boundaries in the Sesia-Dent Blanche nappes are still uncertain, as discussed below. Specifically, the root zone of the RCSZ is of prime importance for understanding the entire system of the Sesia-Dent Blanche nappes. To clarify the implications, several propositions need to be considered (Fig. 6).

\subsubsection{Two nappes scenario (Fig. 6a)}

A first scenario considers the Sesia-Dent Blanche nappes as a composite of only two nappes (Fig. 6a). The Lower Element comprises the Arolla Series, the GMC and the EMC; the Upper Element consists of the Valpelline Series and the II DK (Dal Piaz et al. 1971; Compagnoni et al. 1977a; Gosso et al. 1979; Caby 1981; Spalla et al. 1991; Steck 2008). This scenario ignores the existence of the recently described RCSZ, so far the only well documented nappe boundary (Manzotti et al. 2014a, b). Hence, this scenario will not be discussed further. 
Fig. 5 Geochronological data on the Alpine high-pressure metamorphism in the

Austroalpine nappes of the Eastern Alps, in the Sesia-Dent Blanche nappes, and in the Zermatt-Saas Zone. Blue indicates blueschist facies metamorphism, whereas pink and green depict eclogite facies metamorphism, in the Sesia Zone and in the Zermatt-Saas Zone, respectively. The timing of sedimentation in the Gosau basins (Eastern Alps) is shown for comparison, to emphasize the major difference in evolution between Austroalpine units in the Eastern Alps and the Sesia-Dent Blanche nappes

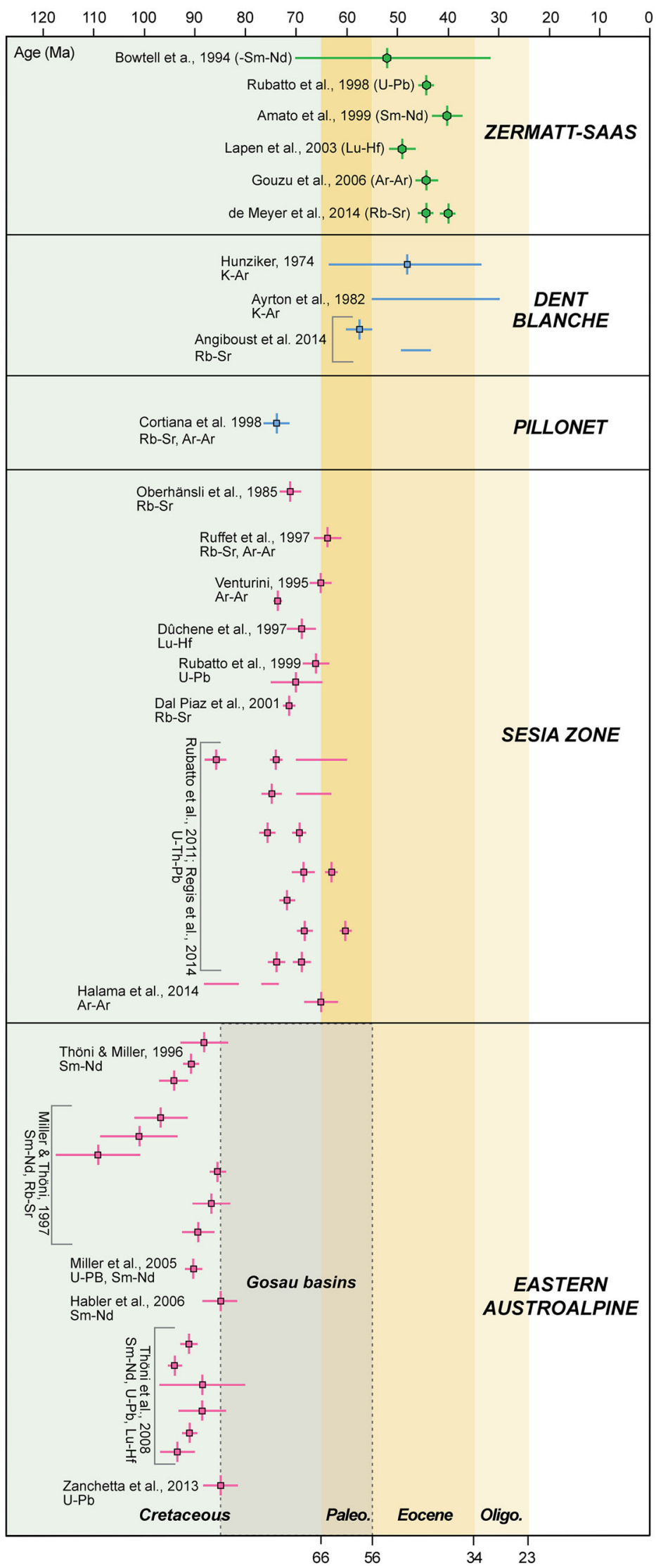


Fig. 6 Cross-sections illustrating possible scenarios for a subdivision of the SesiaDent Blanche nappes: a scenario after Compagnoni et al. (1977b), Gosso et al. (1979), Caby (1981), Spalla et al.(1991); b scenario after Babist et al. (2006), KonradSchmolke et al. (2006); c, d two possible interpretations discussed in the present study. $A S$ Arolla Series of the Dent Blanche nappe s.s., VS Valpelline Series of the Dent Blanche nappe s.s., $L U$ Lower Unit of the Mont Mary nappe, $U U$ Upper Unit of the Mont Mary nappe, EMC Eclogitic Micaschist Complex, GMC Gneiss Minuti Complex, $C Z$ Canavese Zone, $C M B$ CossatoMergozzo-Brissago Line. The two slices depicted in blue in the GMC (d) represent presumed Mesozoic metasediments, such as described at Passo dell'Uomo Storto (Dal Piaz et al. 1971; Gosso et al. 1979) and in the Cima delle Pietre Bianche area

(Compagnoni et al. 1977b; Vuichard 1987). See Sect. 4 for more details. Note that the internal structure of the Piemonte-Liguria units is not shown. In the Sesia-Dent Blanche nappes, thicker lines (in red for the RCSZ) mark the location of the main shear zones. The polyphase internal deformation of each unit cannot be represented at this scale
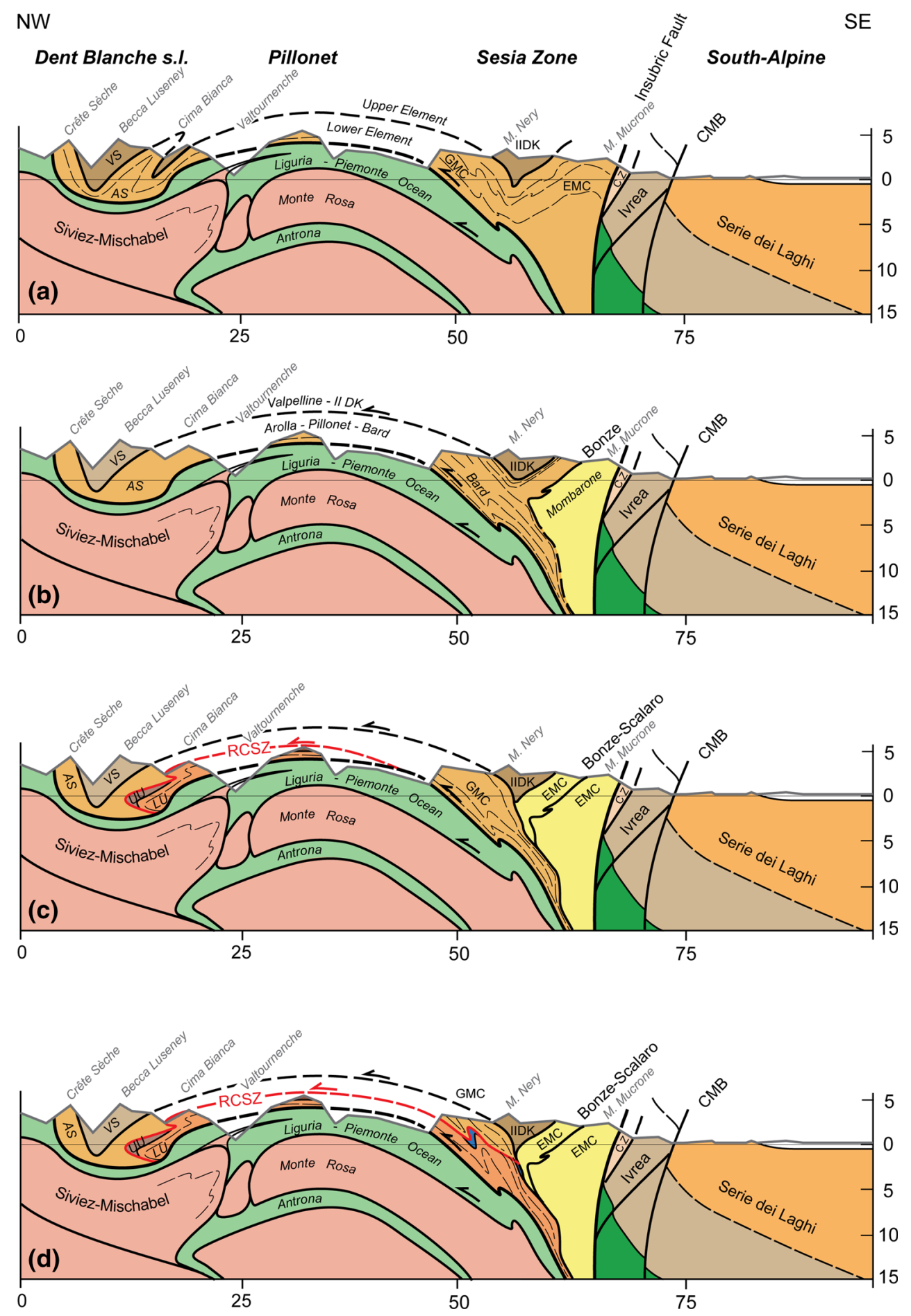

\subsubsection{Three nappes scenario (Fig. 6b)}

A second scenario proposes the existence of three main nappes within the Sesia Zone: the Bard, Mombarone and II DK nappes (Babist et al. 2006; Konrad-Schmolke et al. 2006, 2011a, b) (Fig. 6b). According to these authors the boundary between the Bard and the Mombarone nappes is defined by the Mesozoic meta-sediments of the Bonze unit sensu Venturini et al. (1994). Possible correlations with the DBTS would be as follows: (i) the Bard nappe could be correlated with the Arolla and Pillonet units, and (ii) the Valpelline-II DK nappe would have thrusted the ArollaPillonet-Bard nappe (Fig. 6b). Babist et al. (2006) proposed that the meta-sediments of the Bonze unit, separating 
their Bard and Monbarone nappes from each other, may have been juxtaposed on top of the Valpelline Series-II DK basement by normal faulting in pre-Alpine times (see their Fig. 10a). However, while there is some evidence for the Mont Dolin Series having been deposited atop the altered Arolla Series (Ayrton et al. 1982), no evidence is known for a direct juxtaposition of Mesozoic cover and Valpelline Series in pre-Alpine times. Moreover, this scenario again does not take into account the existence of the RCSZ that separates the Mont Mary nappe from the Dent Blanche s.s. nappe. Hence, this scenario will not be discussed further, the key question being where to extend the RCSZ towards the east.

\subsubsection{Three (or more) nappes scenarios (Fig. 6c, $d$ )}

A third proposal (Fig. 6c) considers three major nappes within the Sesia Zone (i.e. GMC, the II DK, and the EMC, as classically defined on a purely lithological basis, see Rubie 1984; Vuichard 1989), possibly subdivided into not yet identified sub-units or slices. This scenario links the RCSZ with the basal thrust of that part of the Sesia-Dent Blanche nappes which is located east of the Pillonet klippe, i.e. with the base of the external (frontal) part of the Sesia Zone, namely the GMC (Fig. 6c). According to this scenario the GMC would be the equivalent of the Arolla Series. At the same time the Valpelline Series of the DentBlanche s.s. nappe would represent a more external part of the II DK as was assumed by the previous two scenarios. This scenario has the advantage of explicitly taking into account the Mesozoic meta-sediments of the RCSZ that define the traditional nappe boundary between the Dent Blanche s.s. nappe and the Mont Mary nappe. Furthermore, it is compatible with the major lithological difference between the Arolla Series (i.e. orthogneiss derived from a Permian protolith) and the Lower Unit of the Mont Mary nappe (i.e. essentially amphibolite-facies paragneiss).

Since it remains uncertain whether the RCSZ within the Dent Blanche Tectonic System (DBTS) has indeed to be linked with the base of the Sesia Zone, a fourth scenario is proposed (Fig. 6d). This scenario allows correlating the RCSZ to one or several discrete thrusts within the GMC of the Sesia Zone (Fig. 6d). This proposal integrates the observation of presumably Mesozoic meta-sediments in the GMC (see above Sect. 4) and of slices of intensely retrograded granulite-facies rocks, which have been interpreted as marking tectonic contacts inside the GMC (Novarese 1894; Carraro et al. 1970; Compagnoni et al. 1977a; Minnigh 1977; Vuichard 1987). The prime purpose of this fourth scenario is thus to hypothesize the existence of three (or more) slices in (external parts of) the Sesia Zone. While this is the most complex model, we consider this scenario as plausible. However, further mapping is urgently needed to test this hypothesis, with special attention given to the following questions:

- How many marble-calcschist layers exist within the GMC, how continuously can they be mapped, and what is their geometry? Are they folded? Are they located along shear zones and can these be traced across the GMC even where Mesozoic meta-sediments are lacking?

- Can the layers within the GMC be geometrically linked to those found in the EMC, i.e. the Bonze-Scalaro Unit, in which case the RCSZ would be linked to the boundary between the Bard and Mombarone Units sensu Babist et al. (2006)?

\section{Inferred palaeogeographic position of the Sesia-Dent Blanche units}

\subsection{Pre-orogenic plate configuration}

There is an old and still on-going controversy concerning the palaeogeographic position of the Sesia-Dent Blanche nappes. Resolving this controversy is a key point for the reconstruction of the Alpine evolution. Two lines of reasoning have been followed in the past, which emphasize (i) similarities among Mesozoic meta-sediments that are closely associated with different pieces of continental basement; (ii) analogies amongst basement rocks (i.e. grade and timing of pre-Alpine metamorphism, nature, depth and timing of emplacement of the plutonic bodies, etc.), indicating the structural level of each basement unit within the original pre-Alpine crust. The implications of applying the first criterion were discussed in Sect. 4. The second approach and its implications is presented using a historical perspective in the following section.

Based on lithological analogies of basement rocks, Staub (1917) correlated the Sesia-Dent Blanche nappes with the Margna nappe (Val Malenco, eastern Central Alps, northern Italy). He noted the presence of (pre-Alpine) high-grade metamorphic rocks in the pre-Mesozoic basement of both units and the similarities of the gabbros in the Dent Blanche area with the Fedoz gabbro of the Margna nappe. Staub's view was substantiated by Argand (1934), though he considered the Sesia-Dent Blanche nappes to be Penninic units. Two aspects deserve closer scrutiny. Firstly, it has been shown later that both gabbro suites are of Permian age (Hansmann et al. 1996; Hermann et al. 1997). Secondly, regarding the correlative value of Permian gabbroic complexes, we note that gabbros have intruded at different structural levels. Some are found amongst upper crustal granitoids, e.g. in the Dent Blanche nappe, and these are now bounded by thick shear zones 
(Dal Piaz et al. 1977; Baletti et al. 2012). Other Permian gabbros, e.g. those in the south-western Sesia Zone (Corio and Monastero) and in the Margna nappe (Fedoz), show locally preserved intrusive relationships with granulites of the lower crust (Rebay and Spalla 2001; Rebay 2003) or with uppermost mantle peridotite (Hermann et al. 1997). Hence, the correlation between the Sesia and the Margna nappes is generally accepted today (Froitzheim et al. 1996; Schmid et al. 2004).

Once the existence of an oceanic domain within the Alps was accepted, the question arose as to which palaeomargin the Sesia-Dent Blanche nappes once belonged and what their position was with respect to the PiemonteLiguria Ocean. In view of the considerable similarities between the pre-Mesozoic basement of the Southern Alps (Ivrea Zone and Strona Ceneri Zone) and those found in the Sesia-Dent Blanche nappes (e.g. II DK and Arolla Series) virtually all authors considered the Sesia-Dent Blanche nappes as a part of the Adria continental margin. The exact structural and hence palaeogeographic relation with the Piemonte-Liguria Ocean remains controversial. Since the Sesia-Dent Blanche nappes are clearly thrust over the most of the preserved relicts of the Piemonte-Liguria Ocean, and are currently lying northwest of the Insubric Line and the Internal Canavese Line forming the northern boundary of the Southern Alps, the Sesia-Dent Blanche nappes were classically considered as "Austroalpine" (i.e. Dal Piaz 1976; Compagnoni et al. 1977a; Gosso et al. 1979). However, some authors (Elter and Pertusati 1973; Trümpy 1976; Froitzheim and Manatschal 1996; Froitzheim et al. 1996; Handy 1996; Schmid et al. 2004; Handy et al. 2010) proposed that the Sesia-Margna nappes represent a microcontinent that became separated from the distal part of the Adriatic palaeomargin by a narrow oceanic corridor or a narrow strip of exhumed mantle whose remnants would have to be located southeast of the Sesia Zone. Support for this hypothesis comes from several arguments.

1. The geochronological data indicate that the Alpine tectonometamorphic evolution of the Sesia-Dent Blanche nappes is distinctly younger compared with that in the Austroalpine nappes of the Eastern Alps (see Fig. 5 and included references). In the Eastern Alps, high pressure metamorphism in the Saualpe and the Koralpe (i.e. Thöni and Miller 1996; Miller and Thöni 1997; Thöni et al. 2008), in the Porhorje (Thöni 2006; Miller et al. 2005), as well as in the Texel Complex (Habler et al. 2006; Zanchetta et al. 2013), is distinctly earlier (pre-95 Ma) in age (Thöni 2006). In these areas, continental subduction is followed by a phase of extension and deposition of the autochthonous Gosau sediments (Fig. 5) during the Late Cretaceous (Froitzheim et al. 1994; Faupl and
Wagreich 1996; Wagreich and Decker 2011). By contrast, the high-pressure metamorphism of the Sesia Zone in the Western Alps has been dated as Late Cretaceous (i.e. Oberhänsli et al. 1985; Ruffet et al. 1997; Rubatto et al. 1999, 2011; Schmid et al. 2004; Halama et al. 2014; Regis et al. 2014).

2. The continental subduction (85-60 Ma, Fig. 5) in the internal Western Alps is coeval with the deposition of the earliest flysch (Nappe Supérieure, formerly Simme Nappe; Caron et al. 1989) in the Western Alps (Fig. 5). These flysch sediments record the erosion of a Mesozoic platform and a pre-Alpine basement similar to that of the Southern Alps, and they were partly deposited on top of the oceanic crust of the most internal Piemonte-Liguria Ocean and in the front of a Late Cretaceous orogenic wedge. Interestingly, it has been known for a long time that the root zone of this Nappe Supérieure (or Simme nappe) is located south of the Sesia-Dent Blanche nappes and north of the Ivrea Zone of the Southern Alps, namely in the Canavese Zone (Elter et al. 1966; Elter and Pertusati 1973), sandwiched between Internal and External Canavese Line.

In summary, and combining all the evidence, the SesiaDent Blanche-Margna nappes together with the Canavese Zone are all recognized to have originated from the most distal Adriatic margin. However, the Sesia-Dent BlancheMargna nappes and the Austroalpine nappes exhibit major differences in terms of their Cretaceous tectonometamorphic evolution (Froitzheim and Manatschal 1996; Froitzheim et al. 1996; Schmid et al. 2004; Handy et al. 2010).

\subsection{Implications regarding the postulate of tectonic erosion in the Western Alps}

The debate concerning the exact paleogeographic configuration discussed above has major implications concerning the location of the plate boundary during the initial stages of the convergent history in the Western Alps. When assuming that the Sesia-Dent Blanche fragment was never separated from the main Adriatic palaeo-margin, and that the Sesia-Dent Blanche nappes were parts of the upper ("Austroalpine") plate, tectonic erosion (i.e. subduction of slices of continental crust that were sheared off the upper plate) of the Adria continental margin is required to account for the high-pressure metamorphism observed (Polino et al. 1990; Dal Piaz 1993; Angiboust et al. 2014; Lardeaux 2014). Alternatively, if the Sesia-Dent Blanche fragment was separated from the Adriatic palaeomargin by an oceanic basin or a segment of exhumed continental mantle, initial subduction and early thrusting may well 
have occurred along this boundary and the Sesia-Dent Blanche fragment would simply represent the lower plate during this initial subduction stage, the upper plate being represented by the low-grade Canavese Zone and the nonmetamorphic Southern Alps. This scenario implies that tectonic erosion is no longer required for the bulk of the Sesia-Dent Blanche fragment, though it remains a possible mechanism for small fragments that originated from southeast of this fragment during the initial stages of subduction. According to the first scenario discussed above, the Sesia-Dent Blanche fragment originally was part of the upper plate, in the second scenario it represented the lower plate.

It seems that the concept of tectonic erosion would require the subduction of the Piemonte-Liguria Ocean to be contemporaneous with the subduction of pieces of crustal material scraped off the upper plate. However, the age of high-pressure metamorphism in the Piemonte-Liguria Ocean is distinctly and significantly younger than that in the Sesia Zone, which is in conflict with the tectonic erosion model. Theoretically, one could still argue that oceanic subduction began much earlier than is recorded in the fragments of the Piemonte-Liguria Ocean presently exhumed, in which case tectonic erosion could still be a viable mechanism. However, such a view is hardly tenable since there is absolutely no evidence for Cretaceous subduction of Piemonte-Liguria oceanic lithosphere, such as a Cretaceous calc-alkaline arc in the Adriatic plate. If such an arc ever existed, it would have been subsequently removed by subduction or erosion.

The alternative scenario whereby the Sesia-Dent Blanche fragment represents the lower plate requires an extremely thinned continental or even oceanic domain between the future Sesia-Dent Blanche nappes and the Southalpine domain including the Canavese Zone in order to localize the onset of the subduction. The existence of such an oceanic domain was proposed by Elter and Pertusati (1973), Froitzheim et al. (1996), Dal Piaz (1999, 2001) and Pleuger et al. (2007). Direct evidence in favour of such an oceanic domain is scarce and/or disputed. Small slices of serpentinites (lherzolites with harzburgitic layers) are known from the Canavese Zone (at Pesmonte or "Pedimonte"; Elter et al. 1966; Ferrando et al. 2004; Beltrando et al. 2014b), associated with radiolarites whose transgression over the serpentinites is not directly visible but are exposed at a distance of only $20 \mathrm{~m}$ from the serpentinites. However, according to Ferrando et al. (2004) most of the Mesozoic sedimentary sequence of the Canavese Zone is interpreted as deposited on a continental basement. It consists of a pre-rift sequence (PermianTrias), a syn-rift sequence (including breccias with basement clasts: Lower and Middle Jurassic) and a post-rift sequence (radiolarian cherts, "Maiolica", then "argille a
Palombin" of Middle Jurassic to Lower Cretaceous). This feature, together with the occurrence of serpentinites, implies a strongly reduced continental crust, and Ferrando et al. (2004) consider an ocean-continent-transition as the most probable setting. This implies the existence of a nearby oceanic domain, immediately to the northwest of the Canavese Zone, a domain that has been termed "the missing ocean" (Dal Piaz 1999; Dal Piaz et al. 2001).

In summary, we prefer to adopt a pre-orogenic situation whereby a narrow corridor of oceanic lithosphere and/or exhumed subcontinental mantle was present between the Sesia-Dent Blanche fragment and the Southalpine Ivrea Zone. The lack of a calc-alkaline arc remains to be explained, e.g. by referring to the small size of the oceanic domain between Sesia-Dent Blanche fragment and Ivrea Zone. We emphasise that our preferred option does not exclude the possibility of minor tectonic erosion having taken place at the expense of the basement from the distal part of the Adriatic (South-Alpine) palaeomargin. In addition, the recently recognized tectonic slices within the EMC (Regis et al. 2014) may well reflect fragmentation and internal thrusting at or near the contact to the overlying plate. For the sake of (graphical) clarity, such small-scale complexities will not be shown in the evolutionary scheme presented below.

\section{Summary of the orogenic evolution of the Sesia-Dent Blanche nappes}

The data and concepts discussed above have been integrated into a crustal scale evolutionary model of the Western Alps, in spite of the substantial uncertainties inherent in the construction of such a model (Fig. 7). Many of these problems concern the 3D-character of the deformation during the Alpine orogeny, e.g. the dextral displacement along the Insubric Fault, preventing a balanced reconstruction in a 2D-section. However, drawing the geodynamic evolution of the Sesia-Dent Blanche nappes offers the advantage of bringing different scales of observations together and of directly comparing our model with alternative reconstructions at a similar scale (e.g. Dal Piaz 1999; Marthaler 2002; Babist et al. 2006; Lapen et al. 2007; Steck 2008; Handy et al. 2010).

\subsection{Pre-orogenic geometry dominated by crustal-scale normal faults (late Jurassic; Fig. 7a)}

Whether or not the Sesia-Dent Blanche fragment rifted apart as an independent micro-continent or represents the most distal part of the Adriatic margin, its continental crust was probably strongly thinned during Jurassic rifting. In the process of crustal thinning and extension, continental 
Fig. 7 Simplified kinematic model for the evolution of the Sesia-Dent Blanche nappes. The RCSZ is represented by a red line. a Architecture of the margins of the PiemonteLiguria Ocean at the end of the spreading (Late Jurassic); b progressive subduction of the Sesia-Dent Blanche nappes (Late Cretaceous) and development of the RCSZ (deformation stages D3-D4; Manzotti et al. 2014a, b); c subduction of the PiemonteLiguria Ocean (Early Eocene) and folding of the RCSZ (deformation stage D5;

Manzotti et al. 2014a, b); d subduction of the Monte Rosa-Gran Paradiso nappes (Late Eocene-Early Oligocene) associated with early exhumation of the Sesia-Dent Blanche nappes; e large scale deformation of the nappe stack (Late Oligocene). AS Arolla Series, VS Valpelline Series, IIDK Seconda Zona DioriticoKinzigitica, EMC Eclogitic Micaschist Complex, GMC Gneiss Minuti Complex, RCTS Rocca Canavese Thrust Sheets, $C Z$ Canavese Zone. Note that the internal structure of the Piemonte-Liguria units is not shown. In the Sesia-Dent Blanche nappes, thicker lines (in red for the RCSZ) mark the location of the main shear zones. The polyphase internal deformation cannot be represented at this scale
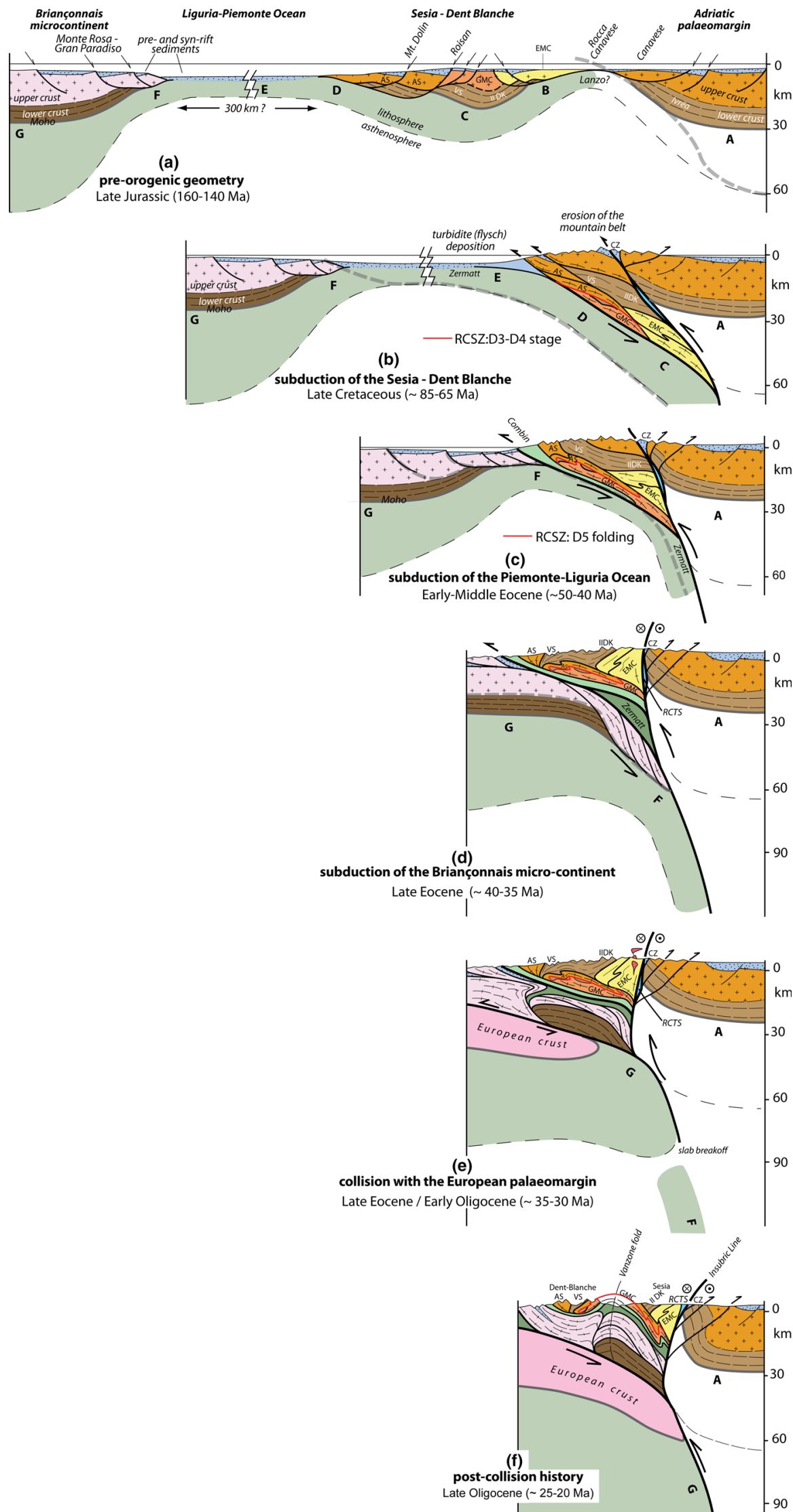
fragments are frequently detached from the (Adriatic) passive continental margin to form isolated allochthonous fragments (extensional allochthons). This process was first documented for the Eastern Alps (Florineth and Froitzheim 1994; Froitzheim and Manatschal 1996) and has recently been extended to the entire Alpine belt (Mohn et al. 2010, 2011; Vitale Brovarone et al. 2011; Beltrando et al. 2014a). Geological evidence typically invoked to support such a model includes the presence of: (i) deep-marine syn- to post-rift sediments in lithostratigraphic contact with serpentinized peridotite or continental basement rocks; (ii) pre-Alpine cataclastic rocks, such as serpentinite breccias that indicate the development of a tectonic contact in the structural domain of brittle deformation; (iii) clasts of continental basement rocks observed in cover sequences at the contact with continental basement slivers (Manatschal and Müntener 2009; Vitale Brovarone et al. 2011). However, within the Sesia-Dent Blanche nappes such metasediments underwent high-pressure metamorphism and high strain. No direct evidence supporting the occurrence of late Jurassic or Cretaceous deep-water sediments such as radiolarites have been found. Furthermore, there is no report of reworked ultramafic clasts in the Mesozoic sequences that would indicate denudated mantle close to carbonate sediments.

For these reasons, the existence of a Sesia-Dent Blanche extensional allochthon remains hypothetical and the postrifting configuration shown in Fig. 7a remains conjectural. The RCSZ, at present a folded Alpine thrust, may correspond to an initially pre-Alpine normal fault (or a series of such faults, not even necessarily all of the same age), reoriented and re-activated during the subduction of the Sesia-Dent Blanche nappes. However, definitive evidence is lacking. The marked lithological difference between the Lower Unit of the Mt Mary nappe and the Arolla Series of the Dent Blanche nappe s.s. (see Manzotti et al. 2014a, b) can be taken as an indicator of the reactivation of a preAlpine structure, either a Jurassic normal fault or an older structure.

\subsection{Subduction of the Sesia-Dent Blanche fragment (Late Cretaceous-Palaeocene; Fig. 7b)}

The earliest Alpine orogenic evidence recognized in the Western Alps is the high-pressure metamorphism and associated deformation in the Sesia Zone (Figs. 3, 5). Much work has focussed on the high- $P$ evolution of the Sesia Zone, where stages of deformation under eclogitefacies conditions were recently dated between $\sim 85$ and $60 \mathrm{Ma}$ (Rubatto et al. 2011; Regis et al. 2014). In the Pillonet klippe the $\mathrm{Rb}-\mathrm{Sr}$ and $\mathrm{Ar}-\mathrm{Ar}$ data are interpreted as evidence of an Upper Cretaceous age ( $75 \mathrm{Ma})$ of the blueschist-facies metamorphic imprint (Cortiana et al.
1998). By contrast, geochronological data in the DentBlanche klippe are scarce. K-Ar ages scatter from to 55 to $30 \mathrm{Ma}$ (Mont Dolin: Ayrton et al. 1982). Rb-Sr ages displaying a range from 58 to $43 \mathrm{Ma}$ (Angiboust et al. 2014) have been interpreted as recording a protracted evolution of the deformation under high pressure metamorphic conditions. The oldest age (58 Ma) has been found in mylonites along the Arolla-Valpelline contact, while younger ages (48-43 Ma) stem from gneisses of the Arolla Series. At present these ages are considered preliminary because of their large uncertainties (the MSWD, i.e. the mean square weighted deviation, of all dated samples range from 19 to 1,003 , and of those retained by the authors between 19 and 928). Some of these ages may reflect a deformation event, but this will require further clarification with respect to the structural history of the area studied by Angiboust et al. (2014). The age of the high-pressure imprint on rocks in the Dent-Blanche klippe thus remains poorly constrained.

Our evolutionary scheme assumes that all of the continental units now constituting the Sesia-Dent Blanche nappes were subducted during the upper Cretaceous and Palaeocene (Fig. 7b).

Some of the Jurassic normal faults may have been reworked and may localize shear zones (thrusts) that delimit different nappes. None of these Jurassic faults have been formally identified up to now in the Sesia-Dent Blanche nappes. However, the RCSZ may well have been a former normal fault, overprinted by ductile shear developed under blueschist facies conditions, which are recorded by mineral assemblages associated with tectonic phases D3 and D4 (Manzotti et al. 2014a, b). During these stages, the basal units of the Sesia-Dent Blanche nappes were affected by intense ductile deformation associated with top-to-NW shearing. Some units, such as the EMC (in yellow on Fig. 7) were subducted to greater depths, while others, essentially those made of dry lower crustal material, show little evidence of a high-pressure overprint. However, scarce kyanite and chloritoid do occur in the Valpelline Series (Kiénast and Nicot 1971), and garnet-glaucophane mylonites have been reported from the boundary between the II DK and the EMC (Lardeaux et al. 1982; Ridley 1989; Vuichard 1989). For these reasons, although the Valpelline Series-II DK unit is shown as a single block in Fig. 7, we assume that the II DK was subducted to greater depths than the Valpelline Series. Piling up the different blocks in order to match the present geometry of the Sesia-Dent Blanche system implies that the fragments were detached from the underlying mantle (see passive markers B, C and D in Fig. 7).

During Late Cretaceous times, some continental units were eroded, as recorded by the deep-water turbidites that filled the trough at the front of the Alpine orogen and that are preserved in the flysch units of the Prealps (Elter et al. 
1966; Homewood and Caron 1982; Homewood and Lateltin 1988; Caron et al. 1989). Sedimentological studies of the clastic material suggest that it derives from a supracrustal basement and its Mesozoic cover akin to the one observed in the Southern Alps (Homewood and Lateltin 1988). Accordingly, Fig. 7 suggests that a mountain range was built during the Late Cretaceous along the frontal part of a convergent zone located southeast of the still largely open Piemonte-Liguria Ocean and consisting of the distal parts of the Adriatic palaeomargin and the uppermost units of the Sesia-Dent Blanche nappes.

\subsection{Subduction of the Piemonte-Liguria Ocean (Early-Middle Eocene; Fig. 7c)}

The next major step in the evolution of the Western Alps is recorded by the eclogite-facies metamorphism in the ophiolites from the Piemonte-Liguria Ocean. Locally, these eclogite-facies ophiolites record ultra-high pressure conditions (Reinecke 1991; Groppo et al. 2009; Frezzotti et al. 2011), whereas others record lower pressures (Groppo et al. 2009; Rebay et al. 2012), indicating that the present assemblage of the ophiolites is made up of slices with different $P-T$ histories. The age of the eclogite-facies metamorphism in the Piemonte-Liguria Ocean is still not well understood. Recent data cluster at around 50 to $40 \mathrm{Ma}$ (Fig. 5, with references therein), but dates up to $60 \mathrm{Ma}$ (see Table 3 of the Supplementary Material in Villa et al. 2014) have been proposed on the basis of poorly constrained LuHf and Sm-Nd two-point isochrons. As the present model centres on the Sesia-Dent Blanche nappes, the neighbouring oceanic units are shown as a single unit in Fig. 7, where internal subdivisions are not represented.

The initial width of the Piemonte-Liguria Ocean (i.e. the distance between the passive markers $\mathrm{E}$ and $\mathrm{F}$ in Fig. 7b) is unknown. Values on the order of $200-300 \mathrm{~km}$ are considered as likely on the basis of the duration of the spreading (at most 20 to $30 \mathrm{Ma}$; Bill et al. 2001; Cordey et al. 2012) and the slow- to ultra-slow spreading rate (i.e. 0.5 to $2 \mathrm{~cm}$ /year; Lagabrielle and Cannat 1990; Lagabrielle 2009). Regardless of the true width of the Piemonte-Liguria Ocean, its subduction implies that the continental slices, now collectively constituting the Sesia-Dent Blanche nappes, were previously accreted to the upper plate (Fig. 7b) above the subducting Piemonte-Liguria oceanic lithosphere (see passive marker F on Fig. 7c) during the Eocene.

During subduction of the Piemonte-Liguria oceanic lithosphere, an accretionary prism was built up and was partially involved in the subduction zone itself. In our model (Fig. 7c) this accretionary prism corresponds to the the Combin (Tsaté) Zone (Marthaler and Stampfli 1989; Escher et al. 1993).
Alternatively, Pleuger and Froitzheim (2005), Pleuger et al. (2007) considered that the Combin (Tsaté) sediments were deposited on the narrow strip of oceanic lithosphere that separated the Sesia-Dent Blanche micro-continent form the Adriatic palaeomargin. In Fig. 7 we have placed the Canavese sediments (Ferrando et al. 2004) in that position, mainly because the Combin Zone is rooted below the Sesia Zone.

During the Piemonte-Liguria oceanic subduction, the Combin Zone was strongly sheared, together with the basal parts of the Sesia-Dent Blanche nappes, resulting in folding and shearing of the previous nappe boundaries. For this reason, we consider that large-scale folding of the RCSZ (D5 folding) took place during this stage, i.e. under greenschist facies conditions (Manzotti et al. 2014a, b).

\subsection{Subduction of the Briançonnais micro-continent (Late Eocene; Fig. 7d)}

Once the oceanic lithosphere was consumed in the subduction zone, the leading edge of the Briançonnais microcontinent became involved in the subduction zone (Fig. 7d). This is recorded by eclogite-facies metamorphism found in the Monte Rosa (Dal Piaz and Lombardo 1986; Lapen et al. 2007) and Gran Paradiso massifs (Dal Piaz and Lombardo 1986; Le Bayon et al. 2006; Gabudianu Radulescu et al. 2009; Gasco et al. 2010). The age of this phase is considered as occurring at 40-35 Ma, i.e. close to the Eocene-Oligocene boundary (Engi et al. 2001; MeffanMain et al. 2004; Lapen et al. 2007; Gabudianu Radulescu et al. 2009).

More external parts of the Briançonnais micro-continent were metamorphosed at lower grades towards the east, with garnet-blueschist assemblages in the west (Ruitor), lawsonite blueschist assemblages in its central part (Vanoise), and finally greenschist or sub-greenschist conditions in the external Zone Houillère (Ellenberger 1958; Valente and Borghi 2000; Bucher and Bousquet 2007; Lanari et al. 2012). The large-scale metamorphic field gradient across the Briançonnais Zone is indicative of an eastward dip of the subduction zone. Fossil-bearing sediments from the Briançonnais Zone were involved in the deformation at blueschist-facies conditions (Raguin 1925; Ellenberger 1958; Michard 1977), and the age of the youngest sediments (Palaeocene i.e. 65 to $55 \mathrm{Ma}$ ) constrains the timing of the metamorphic overprint in that area. Owing to the presence of detrital muscovite in the external Zone Houillère, and because the internal units of the Briançonnais Zone are polycyclic, the age of the high- $P$ imprint is difficult to establish by $\mathrm{K}-\mathrm{Ar}$ (or Ar-Ar) methods (Villa et al. 2014). We surmise that the Briançonnais micro-continent was involved in the subduction zone during Late Eocene time (Fig. 7d). 
The emplacement of eclogite-facies ophiolites on top of the Monte Rosa-Gran Paradiso nappes took place contemporaneously with the subduction of the Briançonnais micro-continent, implying that the ophiolites were detached from the topmost part of the subducting oceanic lithosphere and accreted to the upper plate. It follows that eclogite-facies ophiolites overthrust eclogite-facies basement units, but the age of the eclogite facies imprint in the two units was not the same. This point, which is crucial in the construction of the evolutionary scheme, had been overlooked until precise geochronological data became available (Duchêne et al. 1997; Rubatto et al. 1998; Dal Piaz et al. 2001). This point is also in accordance with kinematic models displaying progressive accretion of crustal slices to the upper plate during the Alpine orogeny (e.g. Malavieille et al. 1984; Ménard and Thouvenot 1984; Butler 1986; Mattauer et al. 1987; Lacassin et al. 1990).

\subsection{Collision with the European palaeomargin (Early Oligocene; Fig. 7e)}

Collision with the European palaeomargin took place once the Valaisan domain was subducted and thrust over the European margin from $35 \mathrm{Ma}$ onwards (Loprieno et al. 2011; Fig. 7e). The main consequence of this event was a reworking of the previous nappe boundaries in the internal part of the Briançonnais Zone, resulting in large-scale, east-facing thrusting and folding (Bucher et al. 2003, 2004) under greenschist-facies conditions. This collision represents a turning point in the Alpine tectonic history, also marked by the transition from flysch to molasse deposition in the flexural basin at the front of the belt (Homewood and Lateltin 1988).

The Sesia-Dent Blanche nappes, which record a considerably older (Late Cretaceous, possibly up to Palaeocene) metamorphism, are located on top of the nappe stack. The evolutionary scheme takes into account the fact that the internal units of the Sesia Zone were exhumed and already resting at the surface in the Oligocene (Zanoni et al. 2008, 2010). This is clear owing to the Biella Volcanic Suite, which rests unconformably on top of the EMC and has been dated at 32-33 Ma (Scheuring et al. 1974; Kapferer et al. 2011; Berger et al. 2012a; Kapferer et al. 2012). This volcanic sequence is associated with the intrusion of numerous dikes that postdate the greenschist facies deformation in the whole Sesia Zone and cut across the different units stacked within the Sesia Zone. Therefore, the main internal tectonic boundaries remained inactive since mid-Oligocene times. A final record of this magmatism is visible in the Biella, Traversella and Miagliano intrusions, which are dated at 33-30 Ma (Berger et al. 2012a). This Periadriatic magmatism requires a significant mantle contribution (Bigioggero et al. 1994;
Callegari et al. 2004), which is provided by partial melting occurring either in the Adriatic lithosphere or in response to slab breakoff (von Blanckenburg and Davies 1995).

\subsection{Post-Oligocene history (Late Oligocene; Fig. 7f)}

Thrust propagation now took place in more external units, ranging, from the Mont-Blanc area to the front of the Jura Mountains (Pfiffner 2009). In the area considered, the entire nappe pile was bent by upright folds (Fig. 7f), the major one being the Vanzone fold (Bearth 1957; Schmid et al. 2004; Keller et al. 2006; Steck 2008). Within the studied area this large-amplitude folding event is not associated with noticeable ductile deformation at the mesoscale, but it is responsible for the overall ductile antiformal folding of the nappe stack. As a result, the basal Dent Blanche thrust is now dipping to the northwest, while the external Sesia boundary is dipping to the southeast. The Pillonet klippe remains approximately horizontal because it is located in the hinge region of the Vanzone fold. The Vanzone fold, the most pronounced fold, is associated with a $60^{\circ}$ clockwise rotation (looking northeast) of the most internal Sesia Zone (Lanza 1977, 1979; Berger et al. 2012b).

This large-scale deformation of the nappe pile is generally considered to be associated with indentation of the rigid Adriatic lithosphere into the Alpine nappe stack (Fig. 7f; Keller et al. 2006). This indentation is accommodated with southeast facing thrusts in the South-Alpine domain, and by underthrusting of the European lower crust below the Penninic nappe stack and the Sesia-Dent Blanche nappes.

The later stages of the post-Oligocene deformation are associated with brittle structures, the two main ones being the brittle top of the Simplon Fault Zone (Mancktelow 1985, 1990) and the Aosta Fault (Stella 1905; Bistacchi et al. 2001). The kinematic link between these two faults is not well understood, and they may have rather complex histories (Malusà et al. 2009), combining along-belt extension with transcurrent sinistral movement. As a result, denudation south of the Aosta Fault took place at a much higher rate than north of that fault, exposing deeper structural levels at the surface. The Sesia-Dent Blanche nappes have been eroded south of the Aosta Fault, and the Combin Zone is preserved in the form of three small klippen resting on top of the Grand Saint Bernard Zone (Grande Sassière, Montjovet and Sana; Ellenberger 1958). North of the Aosta Fault, the Sesia-Dent Blanche nappe is preserved, partly thanks to late brittle structures such as the Trois Villes Fault (Bistacchi and Massironi 2000; Manzotti et al. 2014a, b). The present location of the Dent Blanche s.l. klippe, therefore, is due to the combined effects of folding into a large-scale synform contemporaneous with 
the Vanzone antiform and of brittle graben formation linked to the north-side-down displacement along the Aosta-Ranzola fault and its associates.

Progressive exhumation of the Alpine units is recorded in the molasse basin below the Po plain, where the amount of pebbles derived from the Adriatic units decreases with time (from the Lower Oligocene to the Langhian) while those derived from the oceanic units increase correspondingly. Because pebbles from the Briançonnais basement (i.e. orthogneiss from the Gran Paradiso-Monte Rosa units) first appear in the sedimentary record during the Langhian (16-14 Ma), these units are still shown below the surface at $25 \mathrm{Ma}$ in Fig. 7f (Elter et al. 1966; Polino et al. 1991; Malusà et al. 2005).

\section{Conclusions and perspectives}

This study presents a review of available data on the SesiaDent Blanche nappes, and a synthesis of their orogenic history. The discussion considers lithostratigraphical and sedimentological features, and emphasizes structural and metamorphic characteristics of the evolution of the SesiaDent Blanche nappes since the Permian. Our work shows that:

- Slices of continental crust now forming the Sesia-Dent Blanche nappes were located at substantially different crustal levels in Permian times.

- The Triassic-Jurassic evolution is recorded by Mesozoic meta-sediments. The presence of breccias containing granite clasts indicates erosion of the upper crust, documenting its exhumation along low-angle normal faults during the Jurassic. Undisputable and direct evidence in favour of the original location of the Sesia-Dent Blanche nappes in an ocean-continent transition zone is, however, lacking.

- The Sesia-Dent Blanche nappes experienced heterogeneous strain associated with a polyphase deformation history and an Alpine high pressure-low temperature metamorphism. Even though the high- $P$ imprint is likely to be Late Cretaceous in the entire unit (possibly extending into the Palaeocene in the frontal part), the metamorphic structure shows internal differences, and there may be differences in age.

- Tectonic boundaries within the Sesia-Dent Blanche nappes have been identified using an integrated approach combining the study of (i) the basementcover relationships and the occurrence of Mesozoic meta-sedimentary sheets at the contact between basement rocks; (ii) the differences in pre-Alpine and in Alpine structure and metamorphism (and their relative timing). Based on these findings, the RCSZ analysed in detail by Manzotti et al. (2014a, b) is recognized as an
Alpine shear zone of primary importance; the RCSZ may have re-activated a pre-Alpine fault, along which Mesozoic sediments and slices of pre-Alpine basement are involved.

- All of the data have been integrated into a crustal-scale kinematic model displaying the progressive imbrication of the pieces of oceanic and continental crust during the Alpine orogeny.

Several questions arising from this contribution should be addressed by future work. Firstly, the Cretaceous age of the metamorphism - postulated in our model-remains to be substantiated for the DBTS. Secondly, the structure and evolution of the Rocca Canavese Thrust Sheet needs to be studied in more detail. Although small in size, it may represent a key element for understanding the Alpine orogenic evolution, being located between the metamorphic Alpine nappe stack and the unmetamorphosed South Alpine domain. Thirdly, the links between the continental Sesia Zone and the mantle-derived Lanzo Massif (e.g. Pelletier and Müntener 2006; Kaczmarek and Tommasi 2011) clearly deserve further attention, as Lanzo may preserve evidence of an oceanic domain exhumed during the Jurassic (Lagabrielle et al. 1990; Kaczmarek et al. 2008) and was possibly located between the Sesia-Dent Blanche fragment and the South Alpine crust. Fourthly, age and facies of meta-sediments, sheared and folded with basement rocks, need to be more carefully analysed, especially in order to verify more accurately which exactly are the rocks of Mesozoic age, to delimit the Alpine tectonic boundaries. For example, Mn-rich meta-cherts and carbonates have been traditionally considered as Jurassic in age (e.g. Venturini 1995). While this hypothesis is widely collectively accepted, at least some of these meta-sediments have been shown a Palaeozoic age, as demonstrated in the Sesia Zone and in the DBTS (Castelli and Rubatto 2002; Manzotti et al. 2012, 2014a, b). Resolving these open questions will be useful in testing and refining our proposed model.

Acknowledgments This work was financially supported by the Swiss National Science Foundation (Project 200020-126946). We gratefully acknowledge discussions with Riccardo Bersezio, Giorgio Vittorio Dal Piaz, Guido Gosso, and Daniele Regis. The comments and suggestions of the reviewer, Roberto Compagnoni, have been very helpful. Particularly warm thanks are due to Stefan Schmid, the handling editor of this contribution: his perceptive critique has contributed enormously and has forced us to sharpen the focus and conclusions of this paper. Last but not least, the editorial efforts of A. G. Milnes are greatly appreciated.

\section{References}

Amato, J. M., Johnson, C. M., Baumgartner, L. P., \& Beard, B. L. (1999). Rapid exhumation of the Zermatt-Saas ophiolite deduced from high-precision $\mathrm{Sm}-\mathrm{Nd}$ and $\mathrm{Rb}-\mathrm{Sr}$ geochronology. Earth and Planetary Science Letters, 171, 425-438. 
Angiboust, S., Glodny, J., Oncken, O., \& Chopin, C. (2014). In search of transient subduction interfaces in the Dent Blanche-Sesia Tectonic System (W. Alps). Lithos, 205, 298-321.

Antoine, P., Barbier, R., Debelmas, J., \& Fudral, S. (1972). Précisions chronologique et paléogéographiques sur les bréches du Massif du Grand-Fond (zone des Bréches de Tarentaise, Savoie). Géologie Alpine, 48, 49-59.

Argand, E. (1906). Sur la tectonique du Massif de la Dent Blanche. Comptes Rendus de l'Académie des Sciences Paris, 142, $527-530$

Argand, E. (1908). Carte géologique du Massif de la Dent Blanche (moitié septentrionale), 1:50000, carte spéciale 52. Materiaux pour la carte géologique de la Suisse.

Argand, E. (1909). L'exploration géologique des Alpes pennines centrales. Bulletin de la Société vaudoise des sciences naturelles, 45(166), 217-276.

Argand, E. (1911). L'exploration géologique des Alpes Pennines Centrales. Bulletin des Laboratoires de Géologie de l'Université de Lausanne, 14, 64p.

Argand, E. (1916). Sur l'arc des Alpes Occidentales. Eclogae Geologicae Helvetiae, 14, 145-191.

Argand, E. (1934). La zone pennique. In Guide Géologique de la Suisse. Introductions Générales (Vol. 3, pp. 149-189). Basel: Wepf \& Co.

Aubouin, J., Blanchet, R., Labesse, B., \& Wozniak, J. (1977). Alpes occidentales et Alpes orientales: la zone du Canavese existe-telle? Compte rendu sommaire des séances, Bulletin de la Société géologique de France, 3, 155-158.

Ayrton, S., Bugnon, C., Haarpainter, T., Weidmann, M., \& Frank, E. (1982). Géologie du front de la nappe de la Dent Blanche dans la région des Monts-Dolins, Valais. Eclogae Geologicae Helvetiae, 75, 269-286.

Babist, J., Handy, M. R., Konrad-Schmolke, M., \& Hammerschmidt, (2006). Pre-collisional, multistage exhumation of subducted continental crust: The Sesia Zone, western Alps. Tectonics, 25, TC6008.

Baldelli, C., Dal Piaz, G. V., \& Polino, R. (1983). Le quarziti a manganese e cromo di Varenche-St. Barthélémy, una sequenza di copertura oceanica della falda piemontese. Ofioliti, 8, 207-221.

Baletti, L., Zanoni, D., Spalla, M. I., \& Gosso, G. (2012). Structural and petrographic map of the Sassa gabbro complex (Dent Blanche nappe, Austroalpine tectonic system, Western Alps, Italy). Journal of Maps, 8(4), 413-430.

Ballèvre, M., Kiénast, J. R., \& Vuichard, J. P. (1986). La "nappe de la Dent-Blanche" (Alpes occidentales): Deux unités austroalpines indépendantes. Eclogae Geologicae Helvetiae, 79, 57-74.

Ballèvre, M., \& Merle, O. (1993). The Combin Fault: Compressional reactivation of a Late Cretaceous-Early Tertiary detachment fault in the Western Alps. Schweizerische Mineralogische und Petrographische Mitteilungen, 73, 205-227.

Bearth, P. (1957). Die Umbiegung von Vanzone (Valle Anzasca). Eclogae Geologicae Helvetiae, 50, 161-170.

Bearth, P. (1967). Die Ophiolithe der Zone von Zermatt-Saas Fee. Beiträge zur Geologischen Karte der Schweiz (NF), 132p.

Beltrando, M., Compagnoni, R., Ferrando, S., Mohn, G., Frasca, G., Odasso, N., \& Vukmanovič, Z. (2014b). Crustal thinning and mantle exhumation in the Levone area (Southern Canavese Zone, Western Alps). In G. Manatschal, G. Mohn, E. Masini \& M. Beltrando (Eds.), A Field Guide Across the Margins of Alpine Tethys, Journal of the Virtual Explorer, Electronic Edition, 48, paper 6. ISSN 1441-8142.

Beltrando, M., Manatschal, G., Mohn, G., Dal Piaz, G. V., Vitale Brovarone, A., \& Masini, E. (2014a). Recognizing remnants of magma-poor rifted margins in high-pressure orogenic belts: The Alpine case study. Earth Science Reviews, 131, 88-115.
Berger, A., \& Bousquet, R. (2008). Subduction-related metamorphism in the Alps: Review of isotopic ages based on petrology and their geodynamic consequences. In S. Siegesmund, B. Fügenschuh, N. Froitzheim (Eds.), Tectonic Aspects of the Alpine-Dinaride-Carpathian system. Geological Society of London, Special Publications (Vol. 298, pp. 117-144).

Berger, A., Mercolli, I., Kapferer, N., \& Fügenschuh, B. (2012a). Single and double exhumation of fault blocks in the internal Sesia-Lanzo Zone and the Ivrea-Verbano Zone (Biella, Italy). International Journal of Earth Sciences, 101, 1877-1894.

Berger, A., Thomsen, T. B., Ovtcharova, M., Kapferer, N., \& Mercolli, I. (2012b). Dating emplacement and evolution of the orogenic magmatism in the internal Western Alps: 1. The Miagliano Pluton. Swiss Journal of Geosciences, 105, 49-65.

Bertolani, M. (1964). Le metamorfiti dell'alta Valle Strona (Provincia di Novara). Periodico di Mineralogia, 33, 301-336.

Beslier, M. O., Ask, M., \& Boillot, G. (1993). Ocean-continent boundary in the Iberia Abyssal Plain from multichannel seismic data. Tectonophysics, 218, 383-393.

Bigioggero, B., Colombo, A., Del Moro, A., Gregnanin, A., Macera, P., \& Tunesi, A. (1994). The Oligocene Valle del Cervo Pluton: An example of shoshonitic magmatism in the Western Italian Alps. Memorie degli Istituti di Geologia e Mineralogia dell'Università di Padova, 46, 409-421.

Bill, M., O’Dogherty, L., Guex, J., Baumgartner, P. O., \& Masson, H. (2001). Radiolarite ages in Alpine-Mediterranean ophiolites. Constraints on the oceanic spreading and the Tethys-Atlantic connection. Geological Society of America Bulletin, 113, 129-143.

Bistacchi, A., Dal Piaz, G. V., Massironi, M., Zattin, M., \& Balestrieri, M. L. (2001). The Aosta-Ranzola extensional fault system and Oligocene-Present evolution of the north-western Alpine nappe stack. International Journal of Earth Sciences, 90, 654-667.

Bistacchi, A., Magistroni, C., Spalla, M. I., Gosso, G., Biagini, L., Rossetti, I., et al. (1997). Discovery of eclogitised amphibolites in the IIDK klippe of the Northern Sesia-Lanzo Zone. Quaderni di Geodinamica Alpina e Quaternaria, 4, 158-159.

Bistacchi, A., \& Massironi, M. (2000). Post-nappe brittle tectonics and kinematic evolution of the north-western Alps: An integrated approach. Tectonophysics, 327, 267-292.

Boillot, G., Grimaud, S., Mauffret, A., Mougenot, D., Kornprobst, J., Mergoil-Daniel, J., et al. (1980). Ocean-continent boundary off the Iberia margin: A serpentinite diapir west of the Galicia Bank. Earth and Planetary Science Letters, 48, 22-34.

Bonetto, F., Dal Piaz, G. V., Pennacchioni, G., Tartarotti, P., \& Carraro, F. (2010). Carta geologica d'Italia alla scala 1:50 000, Foglio 091, Châtillon, Servizio Geologico d'Italia.

Bowtell, S. A., Cliff, R. A., \& Barnicoat, C. (1994). Sm-Nd isotopic evidence on the age of eclogitization in the Zermatt-Saas ophiolite. Journal of Metamorphic Geology, 12, 187-196.

Brun, J. P., \& Beslier, M. O. (1996). Mantle exhumation at passive margins. Earth and Planetary Science Letters, 142, 161-173.

Bucher, S., \& Bousquet, R. (2007). Metamorphic evolution of the Briançonnais units along the ECORS-CROP profile (Western Alps): New data on metasedimentary rocks. Swiss Journal of Geosciences, 100, 227-242.

Bucher, K., Fazis, Y., De Capitani, C., \& Grapes, R. (2005). Blueschists, eclogites, and decompression assemblages of the Zermatt-Saas ophiolite: High pressure metamorphism of subducted Tethys lithosphere. American Mineralogist, 90, 821-835.

Bucher, S., Schmid, S. M., Bousquet, R., \& Fügenschuh, B. (2003). Late-stage deformation in a collisional orogen (Western Alps): Nappe refolding, back-thrusting or normal faulting? Terra Nova, $15,109-117$.

Bucher, S., Ulardic, C., Bousquet, R., Ceriani, S., Fügenschuh, B., Gouffon, Y., et al. (2004). Tectonic evolution of the Briançonnais 
units along a transect (ECORS-CROP) through the Italian-French Western Alps. Eclogae Geologicae Helvetiae, 97, 321-345.

Burov, E., Jolivet, L., Le Pourhiet, L., \& Poliakov, A. (2001). A thermomechanical model of exhumation of HP and UHP metamorphic rocks in Alpine mountain belts. Tectonophysics, $342,113-136$.

Bussy, F., Venturini, G., Hunziker, J. C., \& Martinotti, G. (1998). $\mathrm{U}-\mathrm{Pb}$ ages of magmatic rocks of the Western Austroalpine DentBlanche-Sesia Unit. Schweizerische Mineralogische und Petrographische Mitteilungen, 78, 163-168.

Butler, R. W. H. (1986). Thrust tectonics, deep structure and crustal subduction in the Alps and Himalayas. Journal of the Geological Society, London, 143, 857-873.

Butler, J. P., Beaumont, C., \& Jamieson, R. A. (2013). The Alps 1: A working geodynamic model for burial and exhumation of (ultra)high-pressure rocks in Alpine-type orogens. Earth and Planetary Science Letters, 377-378, 114-131.

Caby, R. (1981). Le Mésozoique de la zone du Combin en Val d'Aoste (Alpes graies): imbrications tectoniques entre séries issues des domaines pennique, austroalpin et océanique. Géologie Alpine, 57, 5-13.

Callegari, E., Cigolini, C., Medeot, O., \& D'Antonio, M. (2004). Petrogenesis of calcalkaline and shoshonitic post-collisional Oligocene volcanics of the Cover Series of the Sesia Zone, Western Italian Alps. Geodinamica Acta, 17, 1-29.

Canepa, A., Castelletto, M., Cesare, B., Martin, S., \& Zaggia, L. (1990). The Austroalpine Mont Mary nappe (Italian Western Alps). Memorie di Scienze Geologiche, 42, 1-17.

Caron, C., Homewood, P., \& Wildi, W. (1989). The original Swiss flysch: A reappraisal of the type deposits in the Swiss Prealps. Earth-Science Reviews, 26, 1-45.

Carraro, F., Dal Piaz, G. V., \& Sacchi, R. (1970). Serie di Valpelline e II Zona Diorito-Kinzigitica sono i relitti di un ricoprimento proveniente dalla zona Ivrea-Verbano. Memorie della Società Geologica Italiana, 9, 197-224.

Cartwright, I., \& Barnicoat, A. C. (2002). Petrology, geochronology, and tectonics of shear zones in the Zermatt-Saas and Combin zones of the Western Alps. Journal of Metamorphic Geology, 20, 263-281.

Castelli, D., \& Rubatto, D. (2002). Stability of Al-and F-rich titanite in metacarbonate: Petrologic and isotopic constraints from a polymetamorphic eclogitic marble of the internal Sesia Zone (Western Alps). Contributions to Mineralogy and Petrology, 142, 627-639.

Cenki-Tok, B., Oliot, E., Rubatto, D., Berger, A., Engi, M., Janots, E., et al. (2011). Preservation of Permian allanite within an Alpine eclogite facies shear zone at Mt Mucrone, Italy: Mechanical and chemical behavior of allanite during mylonitization. Lithos, 125, 40-50.

Ciarapica, G., Dal Piaz, G. V., \& Passeri, L. (2010). Late Triassic microfossils in the Roisan zone, Austroalpine Dent BlancheMont Mary nappe system, NW-Alps. Rendiconti Online Società Geologica Italiana, 11, 261.

Collet, L. W. (1935). The structure of the Alps.. London: Arnold.

Compagnoni, R. (1977). The Sesia-Lanzo Zone: High pressure-low temperature metamorphism in the Austroalpine continental margin. Rendiconti della Società Italiana di Mineralogia $e$ Petrologia, 33, 335-378.

Compagnoni, R., Dal Piaz, G. V., Fiora, L., Gosso, G., Lombardo, B., Maffeo, B., et al. (1977a). Excursion to the Sesia-Lanzo Zone and the Valtournanche metamorphic ophiolites. Guide-book. Rendiconti della Società Italiana di Mineralogia e Petrologia, 33, 473-491.

Compagnoni, R., Dal Piaz, G. V., Hunziker, J. C., Gosso, G., Lombardo, B., \& Williams, P. F. (1977b). The Sesia-Lanzo zone, a slice of continental crust with Alpine high pressure-low temperature assemblages in the Western Italian Alps. Rendiconti della Società Italiana di Mineralogia e Petrologia, 33, 281-334.

Compagnoni, R., Engi, M., \& Regis, D. (2014): Val d'Aosta section of the Sesia Zone: Multi-stage HP metamorphism and assembly of a rifted continental margin. In 10th International Eclogite Conference, Syn-Conference Excursion, 5 September 2013, GFT-Geological Field Trips (Vol. 6(1.2), pp. 1-44).

Compagnoni, R., \& Maffeo, B. (1973). Jadeite-bearing metagranites 1.s. and related rocks in the Mount Mucrone area (Sesia-Lanzo Zone, Western Italian Alps). Schweizerische Mineralogische und Petrographische Mitteilungen, 53, 355-378.

Cordey, F., Tricart, P., Guillot, S., \& Schwartz, S. (2012). Dating the Tethyan Ocean in the Western Alps with radiolarite pebbles from synorogenic Oligocene molasse basins (southeast France). Swiss Journal of Geosciences, 105, 39-48.

Cortiana, G., Dal Piaz, G. V., Del Moro, A., Hunziker, J. C., \& Martin, S. (1998). ${ }^{40} \mathrm{Ar}-{ }^{39} \mathrm{Ar}$ and $\mathrm{Rb}-\mathrm{Sr}$ dating of the Pillonet klippe and Sesia-Lanzo basal slice in the Ayas valley and evolution of the Austroalpine-Piedmont nappe stack. Memorie di Scienze Geologiche, 50, 177-194.

Dal Piaz, G. V. (1965). La formazione mesozoica dei calcescisti con pietre verdi fra la Valsesia e la Valtournanche ed i suoi rapporti strutturali con il ricoprimento del Monte Rosa e con la Zona Sesia-Lanzo. Bollettino della Società Geologica Italiana, 84(1), 67-104.

Dal Piaz, G. V. (1976). Il lembo di ricoprimento del Pillonet (falda della Dent Blanche nelle Alpi Occidentali). Memorie di Scienze Geologiche (Padova), 31, 1-60.

Dal Piaz, G. V. (1993). Evolution of the Austroalpine and Upper Penninic basement in the northwestern Alps from Variscan convergence to post Variscan extension. In J. F. von Raumer \& F. Neubauer (Eds.), Pre-Mesozoic Geology in the Alps (pp. 327-344). Berlin: Springer.

Dal Piaz, G. V. (1997). Geology of the Matterhorn and surroundings. Quaderni di Geodinamica Alpina e Quaternaria, 4, 36-37.

Dal Piaz, G. V. (1999). The Austroalpine-Piedmont nappe stack and the puzzle of Alpine Tethys. Memorie di Scienze Geologiche, 51, $155-176$

Dal Piaz, G. V., Cortiana, G., Del Moro, A., Martin, S., Pennacchioni, G., \& Tartarotti, P. (2001). Tertiary age and paleostructural inferences of the eclogitic imprint in the Austroalpine outliers and Zermatt-Saas ophiolite, western Alps. International Journal of Earth Sciences, 90, 668-684.

Dal Piaz, G. V., De Vecchi, G., \& Hunziker, J. C. (1977). The Austroalpine layered gabbros of the Matterhorn and Mt. CollonDents de Bertol. Schweizerische Mineralogische und Petrographische Mitteilungen, 57, 59-88.

Dal Piaz, G. V., Di Battistini, G., Kiénast, J. R., \& Venturelli, G. (1979). Manganiferous quartzitic schists of the Piemonte ophiolite nappe. Memorie di Scienze Geologiche, 32, 4-24.

Dal Piaz, G. V., \& Ernst, W. G. (1978). Areal geology and petrology of eclogites and associated metabasites of the Piemonte ophiolite nappe, breuil-st. Jacques area, Italian Western Alps. Tectonophysics, 51, 99-126.

Dal Piaz, G. V., Gianotti, F., Monopoli, B., Pennacchioni, G., Tartarotti, P., \& Schiavo, A. (2010). Note illustrative della Carta Geologica d'Italia alla scala 1:50.000, Foglio 091 Châtillon. Servizio Geologico d'Italia, Foglio, 091, 5-152.

Dal Piaz, G. V., Gosso, G., \& Martinotti, G. (1971). La II Zona Diorito-Kinzigitica tra la Valsesia e la valle d'Ayas. Memorie della Società Geologica Italiana, 10, 257-276.

Dal Piaz, G. V., Hunziker, J. C., \& Martinotti, G. (1972). La zona Sesia-Lanzo e l'evoluzione tettonico-metamorfica delle Alpi nordoccidentali interne. Memorie della Società Geologica Italiana, 11, 433-466. 
Dal Piaz, G. V., \& Lombardo, B. (1986). Early Alpine eclogite metamorphism in the Penninic Monte Rosa-Gran Paradiso basement of the northwestern Alps. In B.W. Evans \& E.H. Brown (Eds.), Blueschists and Eclogites, Geological Society of America Memoir (Vol. 164, pp. 249-265).

Dal Piaz, G. V., \& Nervo, R. (1971). Il lembo di ricoprimento del Glacier-Rafray (Dent Blanche s.1.). Bollettino della Società Geologica Italiana, 90, 401-414.

Dal Piaz, G. V., \& Sacchi, R. (1969). Osservazioni geologiche sul lembo di ricoprimento del Pillonet (Dent Blanche s.1.). Memorie della Società Geologica Italiana, 7, 835-846.

de Meyer, C. M. C., Baumgartner, L. P., Beard, B. L., \& Johnson, C. M. (2014). Rb-Sr ages from phengite inclusions in garnets from high pressure rocks of the Swiss Western Alps. Earth and Planetary Science Letters, 395, 205-216.

Delleani, F., Spalla, M. I., Castelli, D., \& Gosso, G. (2012). Multiscale structural analysis in the subducted continental crust of the internal Sesia-Lanzo Zone (Monte Mucrone, Western Alps). Journal of the Virtual Explorer, 41, 3-34.

Delleani, F., Spalla, M. I., Castelli, D., \& Gosso, G. (2013a). A new petro-structural map of the Monte Mucrone metagranitoids (Sesia-Lanzo Zone, Western Alps). Journal of Maps, 9, 1-15.

Delleani, F., Zucali, M., Spalla, M. I., \& Gosso, G. (2013b). Map of the strain and reaction-rate partitioning in the Mombarone-Mt. Mucrone area (Sesia Lanzo Zone, Italian Western Alps). Rendiconti Online della Societa Geologica Italiana, 29, 39-42.

Diehl, E. A., Masson, R., \& Stutz, A. H. (1952). Contributo alla conoscenza del ricoprimento della Dent Blanche. Memorie degli Istituti di Geologia e Mineralogia dell'Università di Padova, 17, $1-52$.

Duchêne, S., Blichert-Toft, J., Luais, B., Télouk, P., Lardeaux, J. M., \& Albarède, F. (1997). The Lu-Hf dating of garnets and the ages of the Alpine high-pressure metamorphism. Nature, 387, 586-589.

Ellenberger, F. (1958). Étude géologique du pays de Vanoise (Savoie). PhD dissertation, Uninversité de Paris, Paris, France.

Elter, G. (1960). La zona pennidica dell'alta e media Valle d'Aosta e le unità limitrofe. Memorie degli Istituti di Geologia e Mineralogia dell'Università di Padova, 22, 1-113.

Elter, G. (1971). Schistes lustrés et ophiolites de la zone piémontaise entre Orco et Doire Baltée (Alpes Graies). Hypothèses sur l'origine des ophiolites. Géologie Alpine, 47, 147-169.

Elter, G., Elter, P., Sturani, C., \& Weidmann, M. (1966). Sur la prolongation du domaine ligure de l'Apennin dans le Monferrat et les Alpes et sur l'origine de la Nappe de la Simme s.l. des Préalpes romandes et chablaisiennes. Archives des Sciences, Genève. Bulletin des Laboratoires de géologie, minéralogie, géophysique et du musée géologique de l'Université de Lausanne 167, 279-377.

Elter, P., \& Pertusati, P. (1973). Considerazioni sul limite AlpiApennino e sulle relazioni con l'arco delle Alpi Occidentali. Memorie della Societa Geologica Italiana, 12, 359-375.

Engi, M., Scherrer, N. C., \& Burri, T. (2001). Metamorphic evolution of pelitic rocks of the Monte Rosa nappe: Constraints from petrology and single grain monazite age data. Schweizerische Mineralogische und Petrographische Mitteilungen, 81, 305-328.

Ernst, W. G. (1973). Interpretative synthesis of metamorphism in the Alps. Geological Society of America Bulletin, 84, 2053-2078.

Escher, A., Masson, H., \& Steck, A. (1993). Nappe geometry in the Western Swiss Alps. Journal of Structural Geology, 15, 501-509.

Faupl, P., \& Wagreich, M. (1996). Basin analysis of the Gosau Group of the Northern Calcareous Alps (Turonian-Eocene, Eastern Alps). In G. Welley \& W. Liebl (Eds.) Oil and gas in Alpidic Thrust Belts and Basins of Central and Eastern Europe. EAGE Special Publication (Vol. 5, pp. 127-135).
Ferrando, S., Bernoulli, D., \& Compagnoni, R. (2004). The Canavese zone (internal Western Alps): A distal margin of Adria. Schweizerische Mineralogische und Petrographische Mitteilungen, 84, 1-20.

Florineth, D., \& Froitzheim, N. (1994). Transition from continental to oceanic basement in the Tasna nappe (Engadine window, Graubünden, Switzerland): Evidence for Early Cretaceous opening of the Valais ocean. Schweizerische Mineralogische und Petrographische Mitteilungen, 74, 437-448.

Fountain, D. M. (1976). The Ivrea-Verbano and Strona-Ceneri Zones, northern Italy: A cross-section of the continental crust-new evidence from seismic velocities of rock samples. Tectonophysics, 33, 145-165.

Franz, L., \& Romer, R. L. (2007). Caledonian high-pressure metamorphism in the Strona-Ceneri Zone (Southern Alps of southern Switzerland and northern Italy). Swiss Journal of Geosciences, 100, 457-467.

Frezzotti, M. L., Selverstone, J., Sharp, Z. D., \& Compagnoni, R. (2011). Carbonate dissolution during subduction revealed by diamondbearing rocks from the Alps. Nature Geoscience, 4, 703-706.

Frisch, W. (1979). Tectonic progradation and plate tectonic evolution of the Alps. Tectonophysics, 60, 121-139.

Froitzheim, N., \& Manatschal, G. (1996). Kinematics of Jurassic rifting, mantle exhumation, and passive-margin formation in the Austroalpine and Penninic nappes (eastern Switzerland). Geological Society of America Bulletin, 108, 1120-1133.

Froitzheim, N., Schmid, S. M., \& Conti, P. (1994). Repeated change from crustal shortening to orogen-parallel extension in the Austroalpine units of Graubünden. Eclogae Geologicae Helvetiae, 87, 559-612.

Froitzheim, N., Schmid, S. M., \& Frey, M. (1996). Mesozoic paleogeography and the timing of eclogite-facies metamorphism in the Alps: A working hypothesis. Eclogae Geologicae Helvetiae, 89(1), 81-110.

Gabudianu Radulescu, I., Rubatto, D., Gregory, C., \& Compagnoni, R. (2009). The age of HP metamorphism in the Gran Paradiso Massif, Western Alps: A petrological and geochronological study of "silvery micaschists". Lithos, 110, 95-108.

Gardien, V., Reusser, E., \& Marquer, D. (1994). Pre-Alpine metamorphic evolution of the gneisses from Valpelline series (Western Alps, Italy). Schweizerische Mineralogische und Petrographische Mitteilungen, 74, 489-502.

Gasco, I., Borghi, A., \& Gattiglio, M. (2010). Metamorphic evolution of the Gran Paradiso Massif: A case study of an eclogitic metagabbro and a polymetamorphic glaucophane-garnet micaschist. Lithos, 115, 101-120.

Gerya, T. V., Perchuk, L. L., \& Burg, J.-P. (2008). Transient hot channels: Perpetrating and regurgitating ultrahigh-pressure, high temperature crust-mantle associations in collision belts. Lithos, 103, 236-256.

Gerya, T. V., Stoeckert, B., \& Perchuk, L. L. (2002). Exhumation of high-pressure metamorphic rocks in a subduction channel: A numerical simulation. Tectonics, 21, T10566.

Gosso, G. (1977). Metamorphic evolution and fold history in the eclogite micaschists of the upper Gressoney valley (Sesia-Lanzo zone, Western Alps). Rendiconti della Società Italiana di Mineralogia e Petrologia, 33, 389-407.

Gosso, G., Dal Piaz, G. V., Piovano, V., \& Polino, R. (1979). High pressure emplacement of Early-Alpine nappes, postnappe deformations and structural levels (Internal Northwestern Alps). Memorie degli Istituti di Geologia e Mineralogia dell'Università di Padova, 32, 5-15.

Gosso, G., Messiga, B., Rebay, G., \& Spalla, M. I. (2010). Interplay between deformation and metamorphism during eclogitization of amphibolites in the Sesia-Lanzo Zone of the Western Alps. International Geology Review, 52, 1193-1219. 
Gouzu, C., Itaya, T., Hyodo, H., \& Matsuda, T. (2006). Excess ${ }^{40} \mathrm{Ar}-$ free phengite in ultrahigh-pressure metamorphic rocks from the Lago di Cignana area, Western Alps. Lithos, 92, 418-430.

Groppo, C., Beltrando, M., \& Compagnoni, R. (2009). The P-T path of the ultra-high pressure Lago di Cignana and adjoining highpressure meta-ophiolitic units: Insights into the evolution of the subducting Tethyan slab. Journal of Metamorphic Geology, 27, 207-231.

Habler, G., Thöni, M., \& Sölva, H. (2006). Tracing the high pressure stage in the polymetamorphic Texel Complex (Austroalpine basement unit, Eastern Alps): P-T-t-d constraints. Mineralogy and Petrology, 88, 269-296.

Hagen, T. (1948). Geologie des Mont Dolin und des Nord Randes der Dent Blanche-Decke zwischen Mont Blanc de Cheilon und Ferpècle (Wallis) - 1: 5000. Spezialkarte n. 119. Bern: Beitrag Geologische Karte Schweiz.

Halama, R., Konrad-Schmölke, M., Sudo, M., Marschall, H. R., \& Wiedenbeck, M. (2014). Effects of fluid-rock interaction on ${ }^{40} \mathrm{Ar} /{ }^{39} \mathrm{Ar}$ geochronology in high-pressure rocks (Sesia-Lanzo Zone, Western Alps). Geochimica et Cosmochimica Acta, 126, 475-494.

Handy, M. R. (1996). The transition from passive to active margin tectonics: A case study from the Zone of Samedan (eastern Switzerland). Geologische Rundschau, 85, 832-851.

Handy, M. R., Franz, L., Heller, F., Janott, B., \& Zurbriggen, R. (1999). Multistage accretion and exhumation of the continental crust (Ivrea crustal section, Italy and Switzerland). Tectonics, 18, 1154-1177.

Handy, M. R., Schmid, S. M., Bousquet, R., Kissling, E., \& Bernoulli, D. (2010). Reconciling plate-tectonic reconstructions of Alpine Tethys with the geological-geophysical record of spreading and subduction in the Alps. Earth-Science Reviews, 102, 121-168.

Hansmann, W., Hermann, J., \& Müntener, O. (1996). U-Pb dating of zircons from the Fedoz gabbro, an intrusion located at the crust/ mantle boundary. Schweizerische Mineralogische und Petrographische Mitteilungen, 76, 116-117.

Hermann, J., Müntener, O., Trommsdorff, V., \& Hansmann, W. (1997). Fossil crust-to-mantle transition, Val Malenco (Italian Alps). Journal of Geophysical Research, 102, 20123-20132.

Homewood, P., \& Caron, C. (1982). Flysch of the Western Alps. In K. J. Hsü (Ed.), Mountain Building Processes (pp. 157-168). London: Academic Press.

Homewood, P., \& Lateltin, O. (1988). Classic swiss clastics (flysch and molasse). The Alpine connection. Geodinamica Acta, 2, 1-11.

Hunziker, J. C. (1974). Rb-Sr and K-Ar determination and the Alpine tectonic history of the Western Alps. Memorie degli Istituti di Geologia e Mineralogia dell'Università di Padova, 31, 1-54.

Kaczmarek, M. A., Müntener, O., \& Rubatto (2008). Trace element chemistry and $\mathrm{U}-\mathrm{Pb}$ dating of zircons from oceanic gabbros and their relationship with whole-rock composition (Lanzo, Italian Alps). Contributions to Mineralogy and Petrology, 155, 295-312.

Kaczmarek, M. A., \& Tommasi, A. (2011). Anatomy of an extensional shear zone in the mantle, Lanzo massif, Italy. Geochemistry Geophysics Geosystems, 12(8), 1-24.

Kapferer, N., Mercolli, I., \& Berger, A. (2011). The composition and evolution of an Oligocene regolith on top of the Sesia-Lanzo Zone (Western Alps). International Journal of Earth Sciences, $100,1115-1127$.

Kapferer, N., Mercolli, I., Berger, A., Ovtcharova, M., \& Fügenschuh, B. (2012). Dating emplacement and evolution of the orogenic magmatism in the internal Western Alps: 2. The Biella Volcanic Suite. Swiss Journal of Geosciences, 105, 67-84.

Keller, L. M., Fügenschuh, B., Hess, M., Schneider, B., \& Schmid, S. M. (2006). Simplon fault zone in the western and central Alps: Mechanism of Neogene faulting and folding revisited. Geology, 34(4), 317-320.
Kiénast, J. R. (1973). Sur l'existence de deux séries différentes au sein de l'ensemble "schistes lustrés-ophiolites" du val d'Aoste: quelque arguments fondés sur l'étude des roches métamorphiques. Comptes Rendus de l'Académie des Sciences de Paris, D276, 2621-2624.

Kiénast, J. R. \& Nicot, E. (1971). Présence d'une paragenèse à disthène et chloritoïde (d'âge alpin probable) dans les gneiss à sillimanite, grenat et cordiérite de Valpelline (Val d'Aoste, Italie). Comptes Rendus de l'Académie des Sciences de Paris, D272, 1836-1840.

Konrad-Schmolke, M., Babist, J., Handy, M. R., \& O’Brien, P. J. (2006). The physico-chemical properties of a subducted slab from garnet zonation patterns (Sesia zone, Western Alps). Journal of Petrology, 47, 2123-2148.

Konrad-Schmolke, M., O'Brien, P. J., \& Zack, T. (2011a). Fluid migration above a subducted slab-Constraints on amount, pathways and major element mobility from partially overprinted eclogite-facies rocks (Sesia Zone, Western Alps). Journal of Petrology, 52, 457-486.

Konrad-Schmolke, M., Zack, T., O'Brien, P. J., \& Barth, M. (2011b). Fluid migration above a subducted slab-Thermodynamic and trace element modelling of fluid-rock interaction in partially overprinted eclogite-facies rocks (Sesia Zone, Western Alps). Earth and Planetary Science Letters, 311, 287-298.

Lacassin, R., Tapponnier, P., \& Bourjot, L. (1990). Culminations anticlinales d'échelle crustale et imbrication de la lithospère dans les Alpes, apports du profil ECORS-CROP. Comptes Rendus de l'Académie des Sciences de Paris, II-310, 807-814.

Lagabrielle, Y. (2009). Mantle exhumation and lithospheric spreading: An historical perspective from investigations in the Oceans and in the Alps-Apennines ophiolites. Italian Journal of Geosciences, 128, 279-293.

Lagabrielle, Y., \& Cannat, M. (1990). Alpine Jurassic ophiolites resemble the modern central Atlantic basement. Geology, 18, 319-322.

Lagabrielle, Y., Fudral, S., \& Kiénast, J. R. (1990). La couverture océanique des ultrabasites de Lanzo (Alpes occidentales): Arguments lithostratigraphiques et pétrologiques. Geodinamica Acta, 4, 43-55.

Lanari, P., Guillot, S., Schwartz, S., Vidal, O., Tricart, P., Riel, N., et al. (2012). Diachronous evolution of the Alpine continental subduction wedge: Evidence from P-T estimates in the Briançonnais Zone Houillère (France-Western Alps). Journal of Geodynamics, 56-57, 39-54.

Lanza, R. (1977). Paleomagnetic data from the andesitic and lamprophyric dykes of the Sesia-Lanzo Zone (Western Alps). Schweizerische Mineralogische und Petrographische Mitteilungen, 57, 281-290.

Lanza, R. (1979). Paleomagnetic data from the andesitic cover of the SesiaLanzo Zone (Western Alps). Geologische Rundschau, 68, 83-93.

Lapen, T. J., Johnson, C. M., Baumgartner, L. P., Dal Piaz, G. V., Skora, S., \& Beard, B. L. (2007). Coupling of oceanic and continental crust during Eocene eclogite-facies metamorphism: Evidence from the Monte Rosa nappe, western Alps. Contributions to Mineralogy and Petrology, 153, 139-157.

Lapen, T. J., Johnson, C. M., Baumgartner, L. P., Mahlen, N. J., Beard, B. L., \& Amato, J. M. (2003). Burial rates during prograde metamorphism of an ultra-high-pressure terrane: An example from Lago di Cignana, western Alps, Italy. Earth and Planetary Science Letters, 215, 57-72.

Lardeaux, J. M. (1981). Evolution tectono-métamorphique de la zone nord du massif de Sésia-Lanzo (Alpes Occidentales): un exemple d'éclogitisation de croute continentale. PhD dissertation, Université de Paris, Mémoires des Sciences de la Terre, Paris, 240p.

Lardeaux, J. M. (2014). Deciphering orogeny: A metamorphic perspective. Examples from European Alpine and Variscan belts. Bulletin de la Société Géologique de France, 185, 93-114. 
Lardeaux, J. M., Gosso, G., Kiénast, J.-R., \& Lombardo, B. (1982). Relations entre le métamorphisme et la déformation dans la zone Sesia-Lanzo (Alpes Occidentales) et le problème de l'éclogitisation de la croûte continentale. Bulletin de la Société Géologique de France, 24(7), 793-800.

Lardeaux, J. M., \& Spalla, M. I. (1991). From granulites to eclogites in the Sesia zone (Italian Western Alps): A record of the opening and closure of the Piedmont ocean. Journal of Metamorphic Geology, 9, 35-59.

Le Bayon, B., \& Ballèvre, M. (2006). Deformation history of a subducted continental crust (Gran Paradiso, Western Alps): Continuing crustal shortening during exhumation. Journal of Structural Geology, 28, 793-815.

Le Bayon, B., Pitra, P., Ballèvre, M., \& Bohn, M. (2006). Reconstructing P-T paths during continental collision using multi-stage garnet (Gran Paradiso nappe, Western Alps). Journal of Metamorphic Geology, 24, 477-496.

Lemoine, M. (1971). Données nouvelles sur la série du Gondran près Briançon (Alpes cottiennes). Réflexions sur les problèmes stratigraphique et paléogéographique de la zone piémontaise. Géologie Alpine, 47, 181-201.

Lemoine, M., de Graciansky, P.-C., \& Tricart, P. (2000). De l'océan à la chaîne de montagnes. Tectonique des plaques dans les Alpes. Paris: Gordon and Breach Science Publishers.

Lemoine, M., Tricart, P., \& Boillot, G. (1987). Ultramafic and gabbroic ocean floor of the Ligurian Tethys (Alps, Corsica, Appennines): In search of a genetic model. Geology, 15, 622-625.

Liermann, H. P., Isachsen, C., Altenberger, U., \& Oberhänsli, R. (2002). Behavior of zircon during high-pressure, low-temperature metamorphism: Case study from the Internal Unit of the Sesia Zone (Western Italian Alps). European Journal of Mineralogy, 14, 61-71.

Loprieno, A., Bousquet, R., Bucher, S., Ceriani, S., Dalla Torre, F. H., Fügenschuh, B., et al. (2011). The Valais units in Savoy (France): A key area for understanding the palaeogeography and the tectonic evolution of the Western Alps. International Journal of Earth Sciences, 100, 963-992.

Lugeon, M., \& Argand, E. (1905). Sur les homologies dans les nappes de recouvrement de la zone du Piémont. Comptes Rendus de l'Académie des Sciences de Paris, 140, 1491-1493.

Malavieille, J., Lacassin, R., \& Mattauer, M. (1984). Signification tectonique des linéations d'allongement dans les Alpes occidentales. Bulletin de la Société Géologique de France, 26(7), 895-906.

Malusà, M. G., Polino, R., \& Zattin, M. (2009). Strain partitioning in the axial NW Alps since the Oligocene. Tectonics, 28, 1-26.

Malusà, M. G., Polino, R., Zattin, M., Bigazzi, G., Martin, S., \& Piana, F. (2005). Miocene to Present differential exhumation in the Western Alps: Insights from fission track thermochronology. Tectonics, 24, 1-23.

Manatschal, G., \& Müntener, O. (2009). A type sequence across an ancient magma-poor ocean-continent transition: The example of the western Alpine Tethys ophiolites. Tectonophysics, 473, 4-19.

Manatschal, G., \& Nievergelt, P. (1997). A continent-ocean transition recorded in the Err and Platta nappes (Eastern Switzerland). Eclogae Geologicae Helvetiae, 90, 3-27.

Mancktelow, N. S. (1985). The Simplon Line: A major displacement zone in the Western Lepontine Alps. Eclogae Geologicae Helvetiae, 78, 73-96.

Mancktelow, N. S. (1990). The Simplon Fault Zone. Beiträge zur Geologischen Karte der Schweiz. (N.F.), 163, 74.

Manzotti, P. (2011). Petro-structural map of the Dent Blanche tectonic system between Valpelline and Valtournenche valleys, Western Italian Alps. Journal of Maps, 7, 340-352.

Manzotti, P. (2012). Polycyclic evolution in the Dent Blanche Tectonic System. PhD dissertation, Universität Bern, Bern, Switzerland, 266p.
Manzotti, P., Carlier, Le, de Veslud, C., Le Bayon, B., \& Ballèvre, M. (2014a). Petro-structural map of the Money Unit (Gran Paradiso Massif, Valnontey valley, Western Alps). Journal of Maps, 10(2), 324-340.

Manzotti, P., Rubatto, D., Darling, J., Zucali, M., Cenki-Tok, B., \& Engi, M. (2012). From Permo-Triassic lithospheric thinning to Jurassic rifting at the Adriatic margin: Petrological and geochronological record in Valtournenche (Western Italian Alps). Lithos, 146-147, 276-292.

Manzotti, P., \& Zucali, M. (2013). The pre-Alpine tectonic history of the Austroalpine continental basement in the Valpelline unit (Western Italian Alps). Geological Magazine, 150, 153-172.

Manzotti, P., Zucali, M., Ballèvre, M., Robyr, M., \& Engi, M. (2014b). Geometry and kinematics of the Roisan-Cignana Shear Zone, and the evolution of the Dent Blanche Tectonic System (Western Alps). Swiss Journal of Geosciences, 107, $23-47$.

Marroni, M., Molli, G., Montanini, A., \& Tribzio, R. (1998). The association of continental crust rocks with ophiolites (northern Apennines, Italy): Implications for the continent-ocean transition. Tectonophysics, 292, 43-66.

Marthaler, M. (2002). Le Cervin est-il africain? Une histoire géologique entre les Alpes et notre planète. Lausanne: Loisirs et Pédagogie.

Marthaler, M., \& Stampfli, G. M. (1989). Les Schistes lustrés à ophiolites de la nappe du Tsaté: un ancien prisme d'accrétion issu de la marge active apulienne? Schweizerische Mineralogische und Petrographische Mitteilungen, 69, 211-216.

Martin, S., Tartarotti, P., \& Dal Piaz, G. V. (1994). The Mesozoic ophiolites of the Alps: A review. Bollettino di Geofisica Teorica e Applicata, 36, 175-219.

Masini, E., Manatschal, G., Mohn, G., Ghienne, J. F., \& Lafont, F. (2011). The tectono-sedimentary evolution of a supra-detachment rift basin at a deep-water magma-poor rifted margin: The example of the Samedan Basin preserved in the Err nappe in the SE Switzerland. Basin Research, 23, 652-677.

Masini, E., Manatschal, G., Mohn, G., \& Unternehr, P. (2012). Anatomy and tectono-sedimentary evolution of a rift-related detachment system: The example of the Err detachment (central Alps, SE Switzerland). Geological Society of America Bulletin, 124, 1535-1551.

Matsumoto, K., \& Hirajima, T. (2005). The coexistence of jadeite and omphacite in an eclogite-facies metaquartz diorite from the southern Sesia Zone, western Alps, Italy. Journal of Mineralogical and Petrological Sciences (Japan), 100, 70-84.

Mattauer, M., Malavieille, J., \& Monié, P. (1987). Une coupe lithosphérique des Alpes Occidentales Dans l'hypothèse oû Sezia n'est pas d'origine sudalpine. Comptes Rendus de l'Académie Scienifique de Paris, II-304, 43-48.

Meffan-Main, S., Cliff, R. A., Barnicoat, A. C., Lombardo, B., \& Compagnoni, R. (2004). A Tertiary age for Alpine high-pressure metamorphism in the Gran Paradiso, western Alps: A Rb-Sr microsampling study. Journal of Metamorphic Geology, 22, 267-281.

Ménard, G., \& Thouvenot, F. (1984). Écaillage de la lithosphère européenne sous les Alpes Occidetales: Arguments gravimétriques et sismiques liés à l'anomalie d'Ivrea. Bulletin de la Société Géologique de France, 26(7), 875-884.

Michard, A. (1977). Charriages et métamorphisme haute pression dans les Alpes cottiennes méridionales: à propos des schistes à jadéite de la bande d'Acceglio. Bulletin de la Société Géologique de France, 19, 883-892.

Miller, C., Mundil, R., Thöni, M., \& Konzett, J. (2005). Refining the timing of eclogite metamorphism: A geochemical, petrological, $\mathrm{Sm}-\mathrm{Nd}$ and $\mathrm{U}-\mathrm{Pb}$ case study from the Pohorje Mountains, Slovenia (Eastern Alps). Contributions to Mineralogy and Petrology, 150, 70-84. 
Miller, C., \& Thöni, M. (1997). Eo-Alpine eclogitisation of Permian MORB-type gabbros in the Koralpe (Eastern Alps, Austria): New geochronological, geochemical and petrological data. Chemical Geology, 137, 283-310.

Minnigh, L. D. (1977). A new klippe of "II Zona Diorito-Kinzigitica" in the Sesia-Lanzo Zone. Rendiconti della Società Italiana di Mineralogia e Petrologia, 33, 409-412.

Mohn, G., Manatschal, G., Beltrando, M., Masini, E., \& Kusznir, N. (2012). Necking of continental crust in magma-poor rifted margins: Evidence from the fossil Alpine Tethys margins. Tectonics, 31, TC1012.

Mohn, G., Manatschal, G., Masini, E., \& Müntener, O. (2011). Riftrelated inheritance in orogens: A case study from the Austroalpine nappes in Central Alps (SE-Switzerland and N-Italy). International Journal of Earth Sciences, 100, 937-961.

Mohn, G., Manatschal, G., Müntener, O., Beltrando, M., \& Masini, E. (2010). Unravelling the interaction between tectonic and sedimentary processes during lithospheric thinning in the Alpine Tethys margins. International Journal of Earth Sciences, 99(Supplement 1), S75-S101.

Monjoie, P., Bussy, F., Schaltegger, U., Mulch, A., Lapierre, H., \& Pfeifer, H. R. (2007). Contrasting magma types and timing of intrusion in the Permian layered mafic complex of Mont Collon (Western Alps, Valais, Switzerland): Evidence from U/Pb zircon and ${ }^{40} \mathrm{Ar} /{ }^{39} \mathrm{Ar}$ amphibole dating. Swiss Journal of Geosciences, 100, 125-135.

Negro, F., Bousquet, R., Vils, F., Pellet, C.-M., Halama, R., \& Hänggi-Schaub, J. (2013). Thermal structure and metamorphic evolution of the Piemonte-Liguria metasediments in the northern Western Alps. Swiss Journal of Geosciences, 106, 63-78.

Nicot, E. (1977). Les roches méso- et catazonales de la Valpelline (nappe de la Dent Blanche, Alpes Italiennes). PhD dissertation, Université de Paris VI, Paris, France, 211p.

Novarese, V. (1894). Relazione sul rilevamento eseguito nelle Alpi Occidentali (Valli dell'Orco e della Soana) nella campagna 1893. Bollettino del Regio Comitato Geologico Ialiano, 25, 215-230.

Novarese, V. (1929). La Zona del Canavese e le formazioni adiacenti. Memorie Descrittive della Carta Geologica d'Italia, 22, 65-212.

Oberhänsli, R., Hunziker, J. C., Martinotti, G., \& Stern, W. B. (1985). Geochemistry, geochronology and petrology of Monte Mucrone: An example of eo-Alpine eclogitisation of Permian granitoids in the Sesia Lanzo zone, western Alps. Chemical Geology, 52, $165-184$.

Paquette, J.-L., Chopin, C., \& Peucat, J.-J. (1989). U-Pb zircon, Rb$\mathrm{Sr}$ and $\mathrm{Sm}-\mathrm{Nd}$ geochronology of high to very-high-pressure meta-acidic rocks from the western Alps. Contributions to Mineralogy and Petrology, 101, 280-289.

Passchier, C. W., Urai, J. L., Van Loon, J., \& Williams, P. F. (1981). Structural geology of the Central Sesia-Lanzo Zone. Geologie en Mijnbow, 60, 497-507.

Pelletier, L., \& Müntener, O. (2006). High pressure metamorphism of the Lanzo peridotite and its oceanic cover, and some consequences for the Sesia-Lanzo zone (northwestern Italian Alps). Lithos, 90, 111-130.

Pennacchioni, G., \& Guermani, A. (1993). The mylonites of the Austroalpine Dent Blanche nappe along the northwestern side of the Valpelline Valley (Italian Western Alps). Memorie di Scienze Geologiche, 45, 37-55.

Péron-Pinvidic, G., \& Manatschal, G. (2009). The final rifting evolution at deep magma-poor passive margins from IberiaNewfoundland: A new point of view. International Journal of Earth Sciences, 98, 1581-1597.

Pfiffner, A. (2009). Geologie der Alpen. Bern: Haupt Verlag.

Pfiffner, O. A., Lehner, P., Heitzmann, P., Mueller, S., \& Steck, A. (1997). Deep Structure of the Swiss Alps: Results from NRP 20. Basel: Birkhäuser Verlag.
Pleuger, J., \& Froitzheim, N. (2005). Folded continental and oceanic nappes of the southern side of Monte Rosa (western Alps, Italy): Anatomy of a double collision suture. Tectonics, 24, TC4013$1-22$.

Pleuger, J., Roller, S., Walter, J. M., Jansen, E., \& Froitzheim, N. (2007). Structural evolution of the contact between two Penninic nappes (Zermatt-Saas zone and Combin zone, Western Alps) and implications for the exhumation mechanism and palaegeography. International Journal of Earth Sciences, 96, 229-252.

Pognante, U. (1989a). Lawsonite, blueschist and eclogite formation in the southern Sesia Zone (Western Alps, Italy). European Journal of Mineralogy, 1, 89-104.

Pognante, U. (1989b). Tectonic implications of lawsonite formation in the Sesia Zone (Western Alps). Tectonophysics, 162, 219-227.

Pognante, U., Talarico, F., Rastelli, N., \& Ferrati, N. (1987). High pressure metamorphism in the nappes of the Valle dell'Orco traverse (Western Alps collisional belt). Journal of Metamorphic Geology, 5, 397-414.

Polino, R., Dal Piaz, G. V., \& Gosso, G. (1990). Tectonic erosion at the Adria margin and accretionary processes for the Cretaceous orogeny of the Alps. Mémoires de la Societé Géologique de France, 156, 345-367.

Polino, R., Ruffini, R., \& Ricci, B. (1991). Le molasse terziarie della collina di Torino: relazioni con la cinematica alpina. Atti Ticinesi di Scienze della Terra (Pavia), 34, 85-95.

Quick, J. E., Sinigoi, S., Peressini, G., Demarchi, G., Wooden, J. L., \& Sbisa, A. (2009). Magmatic plumbing of a large Permian caldera exposed to a depth of $25 \mathrm{~km}$. Geology, 37, 603-606.

Quick, J. E., Sinigoi, S., Snoke, A. W., Kalakay, T. J., Mayer, A., \& Peressini, G. (2003). Geologic map of the southern IvreaVerbano Zone, northwestern Italy-Geological Investigations Series Map I-2776, scale 1:25 000. U.S. Geological Survey.

Raguin, E. (1925). Découverte d'une faune de Foraminifères, très probablement crétacés, dans les calcaires hautement métamorphiques du vallon du Paquier, près de la Grande-Motte (Savoie). Comptes Rendus de l'Académie des Sciences de Paris, 181, 726-728.

Rebay, G. (2003). A metamorphic map of the Corio and Monastero gabbro (Southern Sesia-Lanzo zone, NW Italy)-1:10 000. Memorie di Scienze Geologiche, 55, 21-30.

Rebay, G., \& Messiga, B. (2007). Prograde metamorphic evolution and development of chloritoid-bearing eclogitic assemblages in subcontinental metagabbro (Sesia-Lanzo zone, Italy). Lithos, 98, 275-291.

Rebay, G., \& Spalla, M. I. (2001). Emplacement at granulite facies conditions of the Sesia-Lanzo metagabbros: An early record of Permian rifting? Lithos, 58, 85-104.

Rebay, G., Spalla, M. I., \& Zanoni, D. (2012). Interaction of deformation and metamorphism during subduction and exhumation of hydrated oceanic mantle: Insights from the Western Alps. Journal of Metamorphic Geology, 30, 687-702.

Regis, D. (2012). High-pressure evolution in the Sesia terrane (Italian Western Alps). PhD dissertation, Universität Bern, Bern, Switzerland, $151 \mathrm{p}$.

Regis, D., Rubatto, D., Darling, J., Cenki-Tok, B., Zucali, M., \& Engi, M. (2014). Multiple metamorphic stages within an eclogitefacies terrane (Sesia Zone, Western Alps) revealed by $\mathrm{U} / \mathrm{Th}-\mathrm{Pb}$ petrochronology. Journal of Petrology, 55, 1429-1456.

Reinecke, T. (1991). Very-high-pressure metamorphism and uplift of coesite-bearing metasediments from the Zermatt-Saas zone western Alps. European Journal of Mineralogy, 3, 7-17.

Ridley, J. (1989). Structural and metamorphic history of a segment of the Sesia-Lanzo zone, and its bearing on the kinematics of Alpine deformation in the western Alps. Geological Society Special Publications, 45, 189-201. 
Roda, M., Marotta, A. M., \& Spalla, M. I. (2010). Numerical simulations of an ocean-continent convergent system: Influence of subduction geometry and mantle wedge hydration on crustal recycling. Geochemistry, Geophysics, Geosystems, 11, 1-21.

Roda, M., Spalla, M. I., \& Marotta, A. M. (2012). Integration of natural data within a numerical model of ablative subduction: A possible interpretation for the Alpine dynamics of the Austroalpine crust. Journal of Metamorphic Geology, 30, 973-996.

Roda, M., \& Zucali, M. (2008). Meso and microstructural evolution of the Mont Morion metaintrusives complex (Dent Blanche nappe, Austroalpine domain, Valpelline, Western Italian Alps). Italian Journal of Geosciences, 127, 105-123.

Roda, M., \& Zucali, M. (2011). Tectono-metamorphic map of the Mont Morion Permian metaintrusives (Mont Morion-Mont Collon-Matterhorn Complex, Dent Blanche Unit), Valpelline-Western Italian Alps. Journal of Maps, 7, 519-535.

Roure, F., Bergerat F., Damotte, B., Mugnier J.-L. \& Polino R. (1996). The ECORS-CROP Alpine seismic traverse. Mémoires de la Société Géologique de France, 170, 113 p.

Rubatto, D. (2002). Zircon trace element geochemistry: Partitioning with garnet and the link between $\mathrm{U}-\mathrm{Pb}$ ages and metamorphism. Chemical Geology, 184, 123-138.

Rubatto, D., \& Gebauer, D. (1997). The Bonze Unit (Sesia-Lanzo Zone, Western Alps): A gabbroic Early Carboniferous intrusion that recorded Hecynian and Alpine metamorphism. Quaderni di Geodinamica Alpina e Quaternaria, 4, 106-107.

Rubatto, D., Gebauer, D., \& Compagnoni, R. (1999). Dating of eclogite facies zircons: The age of Alpine metamorphism in the Sesia-Lanzo Zone (Western Alps). Earth and Planetary Science Letters, 167, 141-158.

Rubatto, D., Gebauer, D., \& Fanning, M. (1998). Jurassic formation and Eocene subduction of the Zermatt-Saas-Fee ophiolites: Implications for the geodynamic evolution of the Central and Western Alps. Contributions to Mineralogy and Petrology, 132, 269-287.

Rubatto, D., Regis, D., Hermann, J., Boston, K., Engi, M., Beltrando, M., et al. (2011). Yo-Yo subduction recorded by accessory minerals in the Sesia Zone, Western Alps. Nature Geoscience, $241,38-61$.

Rubie, D. C. (1984). A thermal-tectonic model for the high-pressure metamorphism and deformation in the Sesia Zone, Western Alps. The Journal of Geology, 92, 21-36.

Ruffet, G., Gruau, G., Ballèvre, M., Féraud, G., \& Philippot, P. (1997). $\mathrm{Rb}-\mathrm{Sr}$ and ${ }^{40} \mathrm{Ar}-{ }^{39} \mathrm{Ar}$ laser probe dating of high-pressure phengites from the Sesia zone (Western Alps): Underscoring of excess argon and new age constraints of the high-pressure metamorphism. Chemical Geology, 141, 1-18.

Scheuring, B., Ahrendt, H., Hunziker, J. C., \& Zingg, A. (1974). Paleobotanical and geochronological evidence for the Alpine age of the metamorphism in the Sesia-Zone. Geologische Rundschau, 63, 305-326.

Schmid, S. M., Fügenschuh, B., Kissling, E., \& Schuster, R. (2004). Tectonic map and overall architecture of the Alpine orogen. Eclogae Geologicae Helvetiae, 97, 93-117.

Schmid, S. M., \& Kissling, E. (2000). The arc of the Western Alps in the light of geophysical data on deep crustal structure. Tectonics, 19, 62-85.

Sinigoi, S., Quick, J. E., Demarchi, G., \& Peressini, G. (2009). The Sesia magmatic system. Journal of Virtual Explorer, 36, 1-33.

Spalla, M. I., De Maria, L., Gosso, G., Miletto, M., \& Pognante, U. (1983). Deformazione e metamorfismo nel settore esterno della zona Sesia-Lanzo al contatto con la Falda Piemontese ed il Massiccio di Lanzo (Alpi Occidentali). Memorie della Società Geologica Italiana, 26, 499-514.

Spalla, M. I., Gosso, G., Marotta, A. M., Zucali, M., \& Salvi, F. (2010). Analysis of natural tectonic systems coupled with numerical modelling of the polycyclic continental lithosphere of the Alps. International Geology Review, 52, 1268-1302.

Spalla, M. I., Lardeaux, J. M., Dal Piaz, G. V., \& Gosso, G. (1991). Métamorphisme et tectonique à la marge externe de la Zone Sesia-Lanzo (Alpes occidentales). Memorie di Scienze Geologiche, 43, 361-369.

Spalla, M. I., Lardeaux, J. M., Dal Piaz, G. V., Gosso, G., \& Messiga, B. (1996). Tectonic significance of Alpine eclogites. Journal of Geodynamics, 21, 257-285.

Spalla, M. I., Marotta, A. M., Rebay, G., Roda, M., Zanoni, D., Zucali, M., et al. (2014). The transition from Variscan collision to continental break-up in the Alps: Advices from the comparison between natural data and numerical predictions. The Geological Society of London, 405, 363-400. doi:10.1144/SP405.11.

Spalla, M. I., \& Zucali, M. (2004). Deformation vs. metamorphic reequilibration heterogeneities in polymetamorphic rocks: A key to infer quality P-T-d-t path. Rendiconti della Società Italiana di Mineralogia e Petrologia, 73, 249-257.

Spalla, M. I., Zucali, M., Di Paola, S., \& Gosso, G. (2005). A critical assesment of the tectono-thermal memory of rocks and definition of the tectonometamorphic units: Evidence from fabric and degree of metamorphic transformations. In D. Gapais, J.P. Brun, P. Cobbold (Eds.), Deformation Mechanisms, Rheology and Tectonics: From Minerals to the Lithosphere, Geological Society London, Special publications (Vol. 243, pp. 227-247).

Spalla, M. I., \& Zulbati, F. (2003). Structural and petrographic map of the southern Sesia-Lanzo Zone (Monte Soglio-Rocca Canavese, Western Alps, Italy). Memorie di Scienze Geologiche, 55, 119-127.

Sperlich, R. (1988). The transition from crossite to actinolite in metabasites of the Combin unit in Vallée St. Barthélemy (Aosta, Italy). Schweizerische Mineralogische und Petrographische Mitteilungen, 68, 215-224.

Stampfli, G. M. (1993). Le Briançonnais, terrain exotique dans les Alpes? Eclogae Geologicae Helvetiae, 86, 1-45.

Staub, R. (1917). Das Äquivalent der Dent Blanche-Decke in Bünden. Vierteljahrsschritt der naturforschenden Gesellschaft. Zürich, 62, 349-370.

Steck, A. (2008). Tectonics of the Simplon massif and Lepontine gneiss dome: Deformation structures due to collision between the underthrusting European plate and the Adriatic indenter. Swiss Journal of Geosciences, 101, 515-546.

Stella, A. (1905). Il problema geo-tettonico dell'Ossola e del Sempione. Bollettino del Regio Comitato Geologico Ialiano, $36,5-41$.

Stutz, A. H., \& Masson, R. (1938). Zur Tektonik der Dent Blanche Decke. Schweizerische Mineralogische und Petrographische Mitteilungen, 18, 40-53.

Thöni, M. (2006). Dating eclogite-facies metamorphism in the Eastern Alps-Approaches, results, interpretations: A review. Mineralogy and Petrology, 88, 123-148.

Thöni, M., \& Miller, C. (1996). Garnet Sm-Nd data from the Saualpe and the Koralpe (Eastern Alps, Austria): Chronological and P-T constraints on the thermal and tectonic history. Journal of Metamorphic Geology, 14, 453-466.

Thöni, M., Miller, C., Blichert-Toft, J., Whitehouse, M. J., Konzett, J., \& Zanetti, A. (2008). Timing of high-pressure metamorphism and exhumation of the eclogite type-locality (KupplerbrunnPrickler Halt, Saualpe, south-eastern Austria): Constraints from correlations of the $\mathrm{Sm}-\mathrm{Nd}, \mathrm{Lu}-\mathrm{Hf}, \mathrm{U}-\mathrm{Pb}$ and $\mathrm{Rb}-\mathrm{Sr}$ isotopic systems. Journal of Metamorphic Geology, 26, 561-581.

Tropper, P., \& Essene, E. J. (2002). Thermobarometry in eclogites with multiple stages of mineral growth: An example from the Sesia-Lanzo Zone (Western Alps, Italy). Schweizerische Mineralogische und Petrographische Mitteilungen, 82, 487-514. 
Trümpy, R. (1976). Du Pèlerin aux Pyrénées. Eclogae Geologicae Helvetiae, 69(2), 249-264.

Trümpy, R. (1980). Geology of Switzerland, a Guide Book. Part A, An Outline of the Geology of Switzerland. Basel: Wepf \& Co.

Valente, A., \& Borghi, A. (2000). Tectono-metamorphic evolution of the anthracite-bearing Basin of La Thuile (External Briançonnais Zone). Géologie Alpine, 76, 151-163.

Venturini, G. (1995). Geology, geochemistry and geochronology of the inner central Sesia Zone (Western Alps, Italy). Mémoires de Géologie (Lausanne), 25, 1-143.

Venturini, G., Martinotti, G., Armando, G., Barbero, M., \& Hunziker, J. C. (1994). The Central Sesia Lanzo Zone (Western Italian Alps): New field observations and lithostratigraphic subdivisions. Schweizerische Mineralogische und Petrographische Mitteilungen, 74, 115-125.

Venturini, G., Martinotti, G., \& Hunziker, J. C. (1991). The protoliths of the "eclogitic micaschists" in the Lower Aosta Valley (SesiaLanzo Zone, Western Alps). Memorie degli Istituti di Geologia e Mineralogia dell'Università di Padova, 43, 347-359.

Villa, I. M., Bucher, S., Bousquet, R., Kleinhanns, I. C., \& Schmid, S. M. (2014). Dating polygenic metamorphic assemblages along a transect across the Western Alps. Journal of Petrology, 55, 803-830.

Vitale Brovarone, A., Beltrando, M., Malavielle, J., Giuntoli, F., Tondella, E., Groppo, C., et al. (2011). Inherited OceanContinent Transition zones in deeply subducted terranes: Insights from Alpine Corsica. Lithos, 124, 273-290.

Vogler, W. S. (1984). Alpine structures and metamorphism at the Pillonet klippe-A remnant of the Austroalpine Nappe System in the Italian Western Alps. Geologische Rundschau, 73, 175-206.

von Blanckenburg, F., \& Davies, J. H. (1995). Slab breakoff: A model for syncollisional magmatism and tectonics in the Alps. Tectonics, $14,120-131$.

Vuichard, J. P. (1986). Cinématique éo-alpine et alpine en zone SesiaLanzo (Alpes occidentales internes). Comptes Rendus de l'Académie des Sciences de Paris, 303, 1333-1338.

Vuichard, J. P. (1987). Conditions P-T du métamorphisme anté-alpin dans la "seconde zone diorito-kinzigitique" (Zone Sesia-Lanzo, Alpes occidentales). Schweizerische Mineralogische und Petrographische Mitteilungen, 67, 257-271.

Vuichard, J. P. (1989). La marge Austroalpine durant la collision alpine: évolution tectonométamorphique de la zone Sesia-Lanzo. Mémoires et Documents du Centre Armoricain d'Etude Structurale des Socles (Rennes), 24, 307p.

Wagreich, M., \& Decker, K. (2011). Sedimentary tectonics and subsidence modelling of the type Upper Cretaceous Gosau basin (Northern Calcareous Alps, Austria). International Journal of Earth Sciences, 90, 714-726.

Weidmann, M., \& Zaninetti, L. (1974). Quelques données sur la série du Mont-Dolin (nappe de la Dent-Blanche, Valais). Eclogae Geologicae Helvetiae, 67(3), 597-603.
Williams, P. F., \& Compagnoni, R. (1983). Deformation and metamorphism in the Bard area of the Sesia Lanzo Zone, Western Alps, during subduction and uplift. Journal of Metamorphic Geology, 1, 117-140.

Zanchetta, S., Poli, S., Rubatto, D., Zanchi, A., \& Bove, M. G. (2013). Evidence for deep subduction of Austroalpine crust (Texel Complex, NE Italy). Rendiconti Lincei, 24, 163-176.

Zanoni, D., Spalla, M. I., \& Gosso, G. (2010). Structure and PT estimates across late-collisional plutons: Constraints on the exhumation of western Alpine continental HP units. International Geology Review, 55, 1244-1267.

Zanoni, D., Spalla, M. I., Zucali, M., \& Gosso, G. (2008). Structural analysis of the Northeastern margin of the Tertiary intrusive stock of Biella (Western Alps, Italy). Bollettino della Società Geologica Italiana, 127, 125-140.

Zucali, M. (2011). Coronitic microstructures in patchy eclogitised continental crust: The Lago della Vecchia pre-Alpine metagranite (Sesia-Lanzo Zone, Western Italian Alps). Journal of the Virtual Explorer, 38, 3-28.

Zucali, M., Cantù, M., \& Spalla, M. I. (2012). Contrasting tectonometamorphic evolutions in the southern Sesia-Lanzo Zone (Rocca Canavese Thrust Sheets, Western Austroalpine domain) inferred by multi scale structural analysis. Rendiconti online della Società Geologica Italiana, 22, 247-250.

Zucali, M., Manzotti, P., Diella, V., Pesenti, C., Risplendente, A., Darling, J., et al. (2011). Permian tectonometamorphic evolution of the Dent-Blanche Unit (Austroalpine domain, Western Italian Alps). Rendiconti online della Società Geologica Italiana, 15, 133-136.

Zucali, M., \& Spalla, M. I. (2011). Prograde lawsonite during the flow of continental crust in the Alpine subduction: Strain vs. metamorphism partitioning, a field-analysis approach to infer tectonometamorphic evolutions (Sesia-Lanzo Zone, Western Italian Alps). Journal of Structural Geology, 33, 381-398.

Zucali, M., Spalla, M. I., \& Gosso, G. (2002). Strain partitioning and fabric evolution as a correlation tool: The example of the Eclogitic Micaschists Complex in the Sesia-Lanzo Zone (Monte Mucrone-Monte Mars, Western Alps, Italy). Schweizerische Mineralogische und Petrographische Mitteilungen, 82, 429-454.

Zucali, M., Vho, A., Chateigner, D., Lutterotti, L., \& Ouladdiaf, B. (2013). Microstructures and LPO as indicators of strain partition in metamorphic tectonites: The example of the Eclogite Micaschists Complex (Sesia-Lanzo Zone, Austroalpine domain, Western Alps, Italy). Rendiconti Online della Societa Geologica Italiana, 29, 202-205.

Zulbati, F., \& Spalla, M. I. (2003). Structural and petrographic map of the southern Sesia-Lanzo zone (Monte Soglio-Rocca Canavese, western Alps, Italy). Memorie di Scienze Geologiche, 55, $119-127$. 